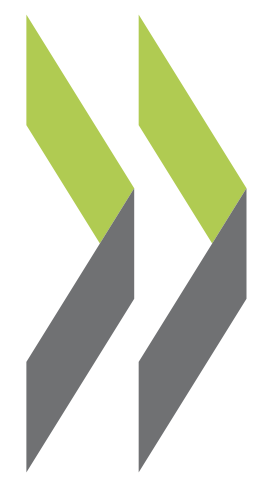

OECD Economics Department Working Papers No. 180

\author{
Regulation \\ and Performance \\ in the Distribution Sector
}

Dirk Pilat 


\section{ECONOMICS DEPARTMENT \\ WORKING PAPERS \\ No. 180 \\ REGULATION AND PERFORMANCE \\ IN THE DISTRIBUTION SECTOR}

by

Dirk Pilat

ORGANISATION FOR ECONOMIC CO-OPERATION AND DEVELOPMENT

Paris

55422

Document complet disponible sur OLIS dans son format d'origine

Complete document available on OLIS in its original format 


\section{REGULATION AND PERFORMANCE IN THE DISTRIBUTION SECTOR}

This paper discusses the impact of government-imposed regulations on performance in the distribution sector. It first deals with the role of the distribution sector in OECD economies and gives an overview of competitive conditions in the sector. Next, it provides an overview of recent evidence concerning the impact of regulation. The paper finds that a range of regulations, including restrictions on large stores, opening hours and zoning, have slowed down structural change in the distribution sector. These regulations have sometimes reduced the efficiency of the distribution system, but have mainly limited the range of services provided to consumers.

$* * * * *$

\section{RÉGLEMENTATIONS ET PERFORMANCES DANS LE SECTEUR DE LA DISTRIBUTION}

Cette étude a pour but d'examiner les effets des réglementations, imposées par les gouvernements, sur les performances du secteur de la distribution. Elle traite en premier, du rôle du secteur de la distribution dans les économies de l'OCDE et donne une vue d'ensemble sur les conditions de concurrence. Elle fournit ensuite, les récentes évidences de l'impact des réglementations. Cette étude constate qu'un ensemble de réglementations, y compris les restrictions concernant les grandes surfaces, les heures d'ouverture et les emplacements, retarde les changements structurels dans le secteur de la distribution. Ces réglementations ont parfois réduit l'efficience du système de distribution, mais ont surtout limité le nombre de services offerts aux consommateurs.

\section{Copyright OECD 1997}

Application for permission to reproduce or translate all, or part of this material, should be made to: Head of Publication Service, OECD, 2 rue André-Pascal, 75775 Paris Cedex 16, France 


\title{
REGULATION AND PERFORMANCE IN THE DISTRIBUTION SECTOR
}

\author{
Dirk Pilat ${ }^{1}$
}

\section{Introduction}

1. As the basic link between producer and consumer, the distribution sector is vital to the functioning of a market economy. Moreover, the sector is in principle structurally competitive. Studies at the OECD and elsewhere have identified government regulation as an important restraint on competition in distribution markets, but the analysis thus far has not been very comprehensive. This underlying study intends to fill some of that void: firstly, by illustrating the importance of the distribution sector and the effect of competition on the development of the distribution sector in OECD member countries; secondly, by showing how particular government regulations have increased costs, distorted incentives and reduced consumer benefits. The ultimate objective of the study is to help governments design and implement regulatory reforms that improve consumer welfare, principally by eliminating or modifying government regulations that impose unjustified and costly restrictions on competition. The rapid changes in the distribution sector over the past decades may also have made existing regulations more and more outdated (Dawson, 1995).

2. The underlying paper is part of a wider study at the OECD that examines the impact of regulation on the distribution sector. That study will look in more detail at trade and international aspects of the distribution sector, the role of competition policy, and permitting and licensing requirements. The current paper discusses some of these issues, but leaves a more comprehensive debate to this wider study. The paper is divided into two parts. Section 2 discusses the role of the distribution sector in the economy and provides an overview of competitive conditions in the sector. The final section analyses the effects of regulation on performance, based on a survey of available literature and a range of empirical evidence.

\section{Competition in the distribution sector}

\subsection{The distribution sector in the economy}

3. The distribution sector is an important part of the economy. It is the principal link between producer and consumer, and plays a major role in price formation. As distribution margins -- the difference between the off-factory price of a good and the price to consumers -- may make up between 10 and 50 per cent of the price of a consumer good (Table 2.9), an efficient distribution system can contribute considerably to low price levels. The distribution sector also plays a vital role in giving

1. I am grateful to Leigh Sparks, Steve Burt and George Fernie of the Institute of Retail Studies, University of Stirling, for their help with some of the material. Helpful comments were provided by Mike Feiner, Leigh Sparks, Nick Vanston and Terry Winslow. I am indebted to Martine Levasseur, Brenda Livsey-Coates and Sandra Raymond for their assistance. 
consumers a wide choice of goods and associated services. In principle, an efficient and competitive distribution sector can help to enhance consumer welfare.

4. Within the distribution sector, a distinction is usually made between wholesale and retail trade. The retail sector sells directly to the consumer, whereas wholesalers normally take an intermediary role between manufacturers and retailers. However, this distinction is increasingly becoming more difficult to make, as the distribution system is becoming more integrated (EC, 1993a; OECD, 1997).

5. The distribution sector, i.e. wholesale and retail trade taken together, covers a considerable part of the economy (Table 2.1). ${ }^{2}$ In the OECD area, its contribution to economy-wide GDP ranges from slightly less than 8 per cent in Germany and Ireland, to over 15 per cent in the United States, Italy, Australia, Belgium, Mexico and New Zealand. Its contribution to economy-wide employment is even larger, reflecting the relatively low productivity level of the sector, and is typically around 15 per cent of total employment. Most of this is in retailing.

6. There has been substantial growth in the distribution sector over the past 15 years, particularly in Japan, the United States, Luxembourg and the Netherlands (Table 2.2). Employment has also grown substantially, at least in most countries, the main exceptions being Denmark, Finland and Sweden. The fall in employment in the latter two countries appears related to the economic crises that hit both countries in the early 1990s. Labour productivity growth in the sector -- even when imperfectly measured -- has been substantial and has been particularly rapid in Japan, Sweden and Denmark (Figure 2.1). Unfortunately, only few countries have data that allow a decomposition of output and employment growth in wholesale and retail trade. From the countries that have such data, no clear pattern emerges. The United States, Canada and Denmark have had more rapid output growth in wholesale trade than in retail trade, but the reverse is true for Japan and Finland.

7. The distribution sector is also an important contributor to business activity. Typically, between 25 and 30 per cent of all enterprises in the economy are in the distribution sector, ranging from slightly less than 20 per cent in the United States, Denmark and Iceland, to 40 per cent in Greece and Portugal. The relatively large number of distribution enterprises in some countries is related to the small scale of the typical retail enterprise in these countries (Table 2.3).

8. The distribution sector is at varying stages of development in different parts of the OECD. Traditional small shops selling basic products are disappearing in many OECD countries and are increasingly being replaced by larger chain stores (Baily, 1993; EC, 1993). Over time, this development has led to larger shops -- in terms of employment and turn-over -- and a lower density of retail outlets (outlets per inhabitant) (Figure 2.2). To some extent, cross-country differences in outlet density and size of shops are a reflection of the degree to which this process has evolved. Small shops have not disappeared, however. New small shops have emerged, often co-operating in franchise agreements or being part of a large chain of shops. Most of these small shops have re-orientated towards more specialised segments of the market. There is a relative preponderance of small shops in Italy, Belgium, Greece, Portugal and Spain, whereas they are relatively large in the United States, the United Kingdom, Canada, Australia and Switzerland (Table 2.3).

2. A number of studies at the European Commission (EC, 1993; 1993a, 1994) provide a good overview of the distribution sector in Europe. 
9. The size of shops and the density of outlets also reflect structural characteristics of a country. Demand-related phenomena, such as population density, the degree of urbanisation, the participation rate of women in the labour force, access to cars, as well as personal consumption expenditure play an important role in determining outlet density, and explain much of the crosscountry variation in this variable (Flath, 1990; OECD, 1992; Høj, Kato and Pilat, 1996). To some extent, tastes appear to matter as well. For instance, a high demand for fashion may explain why clothing is frequently sold in small shops in France. Regulations, e.g. restrictions on large stores or planning and zoning legislation (see Section 3), may also affect outlet density and efficiency.

10. Many retail enterprises consist of only one shop and, with the exception of the Scandinavian countries, most enterprises in the retail sector are sole proprietorships (Table 2.3). This is particularly the case in the countries of Southern Europe, where family shops are still of great importance (EC, 1994). In most other countries, enterprises with multiple shops have expanded further. In terms of total retail turnover, independent stores are not as dominant as they are in employment terms. This is particularly the case in countries with well developed retail systems, such as those in Northern Europe and the United States. In these countries, multiple chains or stores combined in affiliated systems are the largest contributors to total retail turnover (EC, 1993).

11. A large part of the retailing sector is engaged in food retailing, although this differs considerably among OECD countries. For instance, food retailing enterprises -- i.e. enterprises with food retailing as their main activity -- make up only 20 per cent of all enterprises in Germany, but over 40 per cent in Italy, Ireland and Portugal (Table 2.4; EC, 1994). However, in terms of retail turnover, food remains the most important category. Other important sales categories are textiles, clothing and footwear, household equipment, and motor trades (which includes petrol stations).

12. In terms of worker characteristics, the retail sector differs from many other sectors. It is typically characterised by relatively low wages and employs many low-skilled workers (OECD, 1996). An increasing number of employees in the sector work part-time, particularly in the United Kingdom, Australia and the Netherlands. Half or more of the workers in the sector are women, and the sector often provides a point of entry to the labour market for women (EC, 1996). Furthermore, in comparison with other sectors in the economy, a substantial proportion of total employment is made up of self-employed persons (Table 2.5). Family workers also comprise an important part of the labour force in the sector, in particular in countries with less developed distribution systems.

13. The employment composition may be due for further change. The increasing serviceorientation of the distribution sector has generated a move to higher service standards and could require higher skilled workers (Sparks, 1992). Currently, however, the composition of the distribution work force is still mainly oriented towards low-skilled workers, and the sector remains important in employing some of the least skilled in the economy.

\subsection{Efficiency of the distribution system}

\subsubsection{Labour productivity}

14. An important policy concern regarding the distribution sector is its efficiency. Defining efficiency poses a number of difficulties. In general, the efficiency of a particular industry or sector refers to whether it could produce more or better quality output with the same inputs. It can also refer -- more broadly -- to the quantity of output produced with a given set of inputs (i.e. productivity). 
These concepts are not easy to apply to the distribution sector, as it is quite difficult to define and measure the output of the sector. In principle, the output of the distribution sector refers to a package of goods and services provided to consumers. This package can not be separated from the actual goods sold, which implies it is quite difficult to derive suitable output and efficiency measures. ${ }^{3}$

15. Nevertheless, several studies have attempted to derive efficiency measures. A number of these are shown in Table 2.6, as a range of indicators might point to different aspects of efficiency. A first observation made concerning efficiency in the distribution sector is that larger establishments tend to be more productive. Large establishments can benefit from economies of scale and scope and are often better able to organise their functions. In addition, and as suggested by a study for the United Kingdom (Shaw, et al., 1989), large stores may even more be a reaction to a greater consumer demand for choice and variety. Large establishments are particularly important in those markets where price competition plays a major role, such as food retailing. A first possible indicator of relative efficiency is therefore the average size of retail outlets in employment terms. It appears that the mainly English-speaking countries, as well as Switzerland, are characterised by the largest outlets. The smallest outlets are found in Southern Europe and Belgium.

16. Another indicator of relative efficiency is based on the familiar concept of labour productivity. Two indicators of labour productivity are shown here, the first using the distribution sector's contribution to gross domestic product as the output measure, the second retail sales. ${ }^{4}$ From these calculations, it appears that the United States, Germany, France, Belgium, Luxembourg and Switzerland, have relatively high labour productivity in the distribution sector.

17. A number of caveats should be indicated concerning these measures (EC, 1993). First, due to the high incidence of part-time employment in the sector, employment is a poor measure of labour input. For instance, adjusting for part-time employment substantially increases the relative productivity performance of the Netherlands. Furthermore, countries with low labour productivity may have limited incentives to improve performance if labour costs are relatively low. This may be one of the reasons why labour productivity in UK retailing is relatively low, even though the United Kingdom has a well developed retail sector.

18. The final column of Table 2.6 shows retail sales per retail outlet. This indicator is a good indicator of the average size of stores and the trade channelled through each individual outlet. The United States, Luxembourg and Switzerland have the highest sales per outlet, whereas the Southern European countries and Belgium have very low sales per outlet, reflecting the fragmented retail structure in these countries.

19. As noted above, relative efficiency in the distribution sector is partly related to the presence of larger stores. This finding is confirmed in earlier work (OECD, 1992), where it was shown that large stores can achieve significant economies of scale. In this respect, there are considerable

3. McKinsey (1995) distinguishes between four elements of the value added of the retail sector, namely the efficient distribution of goods, convenience, service and product range. Traditional output measures primarily focus on the first point and have some difficulty in incorporating the other three elements.

4. To enable a cross-country comparison of productivity levels, data on sales and value added were converted to a common currency with a purchasing power parity for consumer goods. This approach has been taken in the past by several studies (e.g. Baily, 1993). 
differences across the OECD area (Table 2.7). Stores have far less sales space in Japan and Southern European countries than they have in the countries of Northern Europe, which prevents them from achieving economies of scale and limits the variety of goods they can offer ${ }^{5}$. In Europe, the average store size is particularly large in Germany, Luxembourg and the Netherlands.

20. Secondly, the density of hypermarkets and their market share differs considerably across OECD-Europe (Tables 2.7 and 2.8). Hypermarkets are particularly important in France, the United Kingdom, Germany and Belgium, but play only a limited role in Italy, Greece, Portugal and the Netherlands. Furthermore, large enterprises -- those employing more than 1000 persons -- are particularly important in the United Kingdom, France, the Netherlands and Germany. Most of these firms have multiple outlets.

21. Differences in labour productivity may have a number of other causes (Dawson, 1995). Productivity growth in existing stores has resulted from the increased use of self-service in many parts of the market, the use of information technology, improved management of inventories and modern management techniques.

\subsubsection{Distribution margins}

22. Labour productivity and related measures are not the only indicators that can be used to gauge the efficiency of the distribution system. A frequently used measure of efficiency is the distribution margin. The margin is measured as the difference between the price of a good as it is sold to the consumer (the purchaser price) and the price of a good as it leaves a factory (the producer price). A low margin could potentially indicate that the distribution system is efficient in channelling goods to the consumer as only little is added to the producer price.

23. A number of complexities arise in comparing these values. The first are transport costs, that contribute to the difference between these two price measures, but that are only partly related to the distribution system. The second are indirect taxes, that form part of the purchaser price, but that should be excluded when assessing the efficiency of the distribution system. Thirdly, differences in margins are also affected by the degree of integration between retailing and wholesaling and by the respective market power of the different players (manufacturers, retailers and wholesalers). Fourthly, higher margins may simply reflect a higher demand for consumer service, as a result of differences in tastes (EC, 1993).

24. Unfortunately, relatively little is known in comparative terms about distribution margins and few countries collect margin data as part of their national statistics. The most detailed source of data on margins are often input-output tables. Table 2.9 shows distribution margins for selected OECD countries and for a number of product categories. As has been found in previous studies (OECD, 1992), the United States does not have the lowest distribution margins on goods for personal consumption, in spite of being regarded as having the most efficient distribution system. As indicated above, this may be an indication of the high service orientation of the US distribution system.

25. Even taking account of the fact that the data are difficult to compare among countries, due to different classifications of goods and differences in accounting systems, there appear to be

5. Data for Japan indicate an average store size of around 60 square metres in the late 1980s. Data for the United States were not available. It should be noted that the measurement of floorspace may differ across countries, implying that differences should be interpreted with care. 
considerable differences in margins across countries. Also, margins differ considerably between different product categories. Among non-durable goods, margins are relatively low on food products, whereas among durable goods they are relatively low on motor vehicles. The low margin on food reflects the type of competition in this category of goods, which is primarily driven by price competition among large outlets. This type of competition implies that the distribution chain adds little value to the basic product. ${ }^{6}$

26. More detailed studies of retail margins suggest that large retail outlets tend to have belowaverage margins (EC, 1993a). Margins may also be lower in specific retail formats, such as discount stores (OECD, 1995). This may imply that low margins might result from the structural transformation of the retail sector, leading to larger outlets, more direct links between manufacturers and retailers, and a growing importance of discount stores. It is not obvious that average margins will fall as a result of these developments, however. To some extent, the growth in large stores and discount stores is compensated by the simultaneous growth of speciality stores and stores with high service. ${ }^{7}$ The latter are likely to contribute to higher margins.

27. An additional complexity in interpreting margins arises from international trade. The necessity to deal with foreign wholesalers may add an additional layer to the distribution system which can contribute to the overall distribution margin (EC, 1993a). This is particularly like to affect countries with a high degree of import penetration. The process of European integration has simplified border procedures within the European Community and could help to remove this extra layer. However, a recent evaluation by the European Commission (EC, 1996a) finds little evidence that distribution margins have fallen as a result of European integration.

\subsection{Changing competitive conditions in the distribution sector}

28. In principle, entry and exit to the distribution sector is quite easy and competition appears well developed. During the 1980s, 375,600 new retail firms opened in the United Kingdom, and 383,600 closed, leading to a net decrease of 8,000 firms (Dawson, 1995). Compared with a total number of firms of around 350,000 by the late 1980s, this suggests considerable turn-over. Entry barriers in some parts of the market have risen over time, however. In these parts, the sunk cost component has increased, due to a larger size of stores. In some cases, local monopolies have emerged, as stores could benefit from establishing at the best sites.

29. Underlying the rapid changes in the distribution sector are a number of factors, foremost among them the changes in consumer demand patterns (Dawson, 1995). Consumers have become more affluent, have changed new life-styles and values, involving moves towards more specialised services and goods. Demographical factors, such as an ageing of the population and smaller households, have also contributed. Furthermore, the higher workforce participation of women has generated demand for time-saving products and for opportunities to shop outside normal working hours. Finally, the changing location of the population may contributed to a shift to out-of-town retailing.

6. This is not necessarily the case. Studies for the United Kingdom (Burt and Sparks, 1997) suggest that food retailers are highly service-oriented and add considerable value to the basic product.

7. Some of these stores might be quite large, further complicating the analysis. 
30. Changes in the distribution sector have also resulted from an economy-wide surge towards greater flexibility, the globalisation of the economy, but also to changing technology (see section 2.4). Technological change has simplified relations between manufacturers and distributors and also led to the development of new forms of distribution (EC, 1994; OECD, 1997). The changing nature of competition in distribution has a number of important aspects, set out in the next five sub-sections.

\subsubsection{Concentration}

31. Large firms have been very successful in many parts of the market. As a result, the sector has become more concentrated. Partly as a result of technological developments, as well as more efficient transport and car ownership, the optimal size of firms has increased. This is particular the case in mass food retailing, where a significant part of the market is characterised by price competition. If price competition is the norm, firms need to be large to compete, as this allows them to achieve economies of scale (Good, 1984) and scope, reduce procurement costs and improve logistics. Such large firms also offer consumers the possibility to find all their needs at one stop (OECD, 1992).

32. However, many small and specialised stores survive in the food market, particularly in areas (including inner cities) where access to large stores is costly, but also in specialised niche markets. Concentration has also increased in other parts of the retail sector, such as furniture and do-it-yourself retailing. However, many other markets, such as clothing, are much less concentrated. Recent figures from the European Commission (EC, 1996a) suggest that the top 10 clothing retailers do not account for half of sales in those European countries for which data are available. The highest market share was estimated for the United Kingdom, where the top 10 companies control about 45 per cent of the clothing market. Some of these markets are characterised by some economies of scope, however (EFTA, 1994), and by increased differentiation in the products and services offered.

33. Concentration is more advanced in some countries than in others (Table 2.10). Some parts of the retailing sector are dominated by a number of large enterprises, each comprising a large number of outlets. As far as European food retailing is concerned, the process of concentration has gone furthest in Norway, Finland and Switzerland, where only three enterprises control more than 80 per cent of the food retailing segment. Concentration is somewhat lower in Germany, the United Kingdom and France, where 3 enterprises control between 40 and 50 per cent of the market. Concentration is also high in a number of other small countries, such as Belgium, Sweden and the Netherlands. ${ }^{8}$ High concentration in smaller economies may arise because of the need to achieve scale economies (EC, 1993a). The process of concentration has hardly touched the countries of Southern Europe, where the three major companies control only 25 per cent or less of the market in food retailing.

34. Large firms may have greater market power than small firms, as they can more easily extract favourable terms when procuring goods, and may also be able to deter entry by advertising outlays or

8. Concentration measures are often not strictly comparable between countries. For instance, the high concentration rate in Sweden refers to the market share of three co-operative groups. The retailers in these groups are relatively independent, but co-operate in certain areas, such as buying and advertising. High concentration resulting from the role of co-operatives may be a much smaller problem, than concentration based on firms with multiple outlets. More work on concentration trends and its impacts may be required, however (Akehurst, 1995). 
access to the best sites. Technological developments (see below), may also favour large stores (OECD, 1997). This process of scale enlargement and increasing market power for large stores could lead to a high degree of concentration and potentially to anti-competitive behaviour by firms (OECD, 1992). However, a large optimal size of firms should not pose a problem by itself, as such firms are likely to be more efficient and produce at lower costs.

35. A recent study of 203 firms in the Northeast region of the United States (Gable, et al., 1995) found some evidence that retailing may indeed no longer be an industry with low barriers to entry. The study distinguished between exogenous and endogenous barriers to entry. Exogenous barriers reflect underlying market conditions and include cost advantages of incumbents, product differentiation of incumbents, capital requirements, access to distribution channels, government policies and customer switching costs. Endogenous barriers are created by the behaviour of established firms, and include the creation of excess capacity, increased promotional activity and retaliatory and pre-emptive pricing. The retail firms were asked to rate how effective these barriers to entry would be in deterring the entry of new competitors in their market area. ${ }^{9}$ Retailers were also asked whether and how they themselves would respond to new entry in their market. The results suggested that the main entry barriers were exogenous to the industry, i.e. capital requirements, availability of store locations, availability of qualified personnel and the distinctive store images of incumbents. Endogenous entry barriers were considered less important, with the most common types of responses being: increased use of sales promotion activities, increased advertising and restructuring of retail prices. These endogenous responses are likely to reinforce exogenous market barriers.

36. Although the findings of this study can not be generalised, they would confirm a process of increased concentration in retailing. However, a number of developments may also undercut the dominant position of large firms (OECD, 1992). First, consumers are better informed and more mobile than in the past, which implies that local monopolies are a smaller risk than in the past. Second, large firms are increasingly able to diversify in new markets by adding new product ranges in an existing outlet, thus overcoming many of the exogenous barriers to entry, which implies that the market segment is often contestable. Thirdly, international competition (see below) has strengthened competition in many markets. Combined, these developments imply that large enterprises are often subject to substantial competition in their market segment, which is confirmed by the relatively low level of profits for such enterprises (OECD, 1992). However, a risk of market dominance remains, particularly in the highly concentrated food segment of the market.

\subsubsection{Vertical integration}

37. The role of the distribution sector has changed significantly over the past decades (Dawson, 1995). In the 1950s and 1960s, the manufacturing sector mass-produced goods that were then channelled as quickly as possible to the consumer, generally moving through wholesaler and retailer before reaching the ultimate consumer. The distribution function was relatively passive, driven by the need of manufacturers to sell their goods. Estimates by the Nielsen company (Dawson, 1995), suggest that about 40 per cent of the value added of a large-volume consumer good in Europe was due to manufacturing, 15 per cent to logistical functions, 25 to marketing and distribution, and the remainder to other functions, such as overhead.

9. One may question whether retailers are really able to rate these barriers. In particular, they may not know who their competitors could be. 
38. By the 1990s, this had changed considerably (Dawson, 1995). Consumer demand had changed, with greater demand for service and quality, and less for quantity as such. The distribution sector has also taken on a much greater task in attempting to determine what consumers want, in targeting specific groups, and by becoming more and more in producing the goods it sells. Major retailers now play an important role in designing and branding new products. As a consequence, the composition of value added has changed considerably. Manufacturing now only adds about 20 per cent to the value added of a large-volume consumer good, the logistics share has increased slightly to about 20 per cent, and distribution and marketing now make up about 40 per cent of value added.

39. The distribution chain from producer to consumer has therefore become much more integrated, with the respective roles of the different parts (manufacturer, wholesaler, retailer) becoming more difficult to separate. In addition, the emergence of large firms in the retailing sector has shifted the balance of power somewhat towards retailers (Dawson, 1995).

40. In the trend towards greater vertical integration of the distribution chain, large retail chains increasingly bypass wholesalers and deal directly with manufacturers, particularly in food retailing (EC, 1996a). Information technology has contributed to this trend (OECD, 1992; 1997), as it allows retailers to fine-tune their inventory needs and also reduce the warehousing role of traditional wholesalers. Furthermore, large retail buying groups often integrate wholesale and retail functions. At the same time, some wholesalers have moved away from traditional activities and diversified their operations, by offering additional services and moving into specialised retailing markets (OECD, 1992).

\subsubsection{Co-operation}

41. To compete in an increasingly concentrated industry, small enterprises increasingly engage in co-operative arrangements, such as buying groups, strategic alliances or franchise agreements. Buying groups have a long history and the European retailing market currently includes a number of large buying groups, combining retailers from many countries.

42. Franchising is also increasingly used. For instance, in 1990 more than 20000 French retailers initiated a franchise chain to face competition from larger chains (EC, 1994). Franchising is also employed as a method to expand the market of a particular retail enterprise, as it allows firms to expand without investing their own capital, is based on local expertise, and allows firms to circumvent local opposition and regulations (EC, 1993a). In addition, franchising allows firms to achieve some economies of scale even where decentralised ownership and supervision are important (OECD, 1992).

43. Apart from buying groups and franchising agreements, four main types of alliances have emerged (Dawson, 1995). First, value adding alliances focus on joint buying arrangements or the development of new retail brands. Second, technology alliances have focused on joint R\&D or the development of modern information technology. Third, joint development alliances aim to develop new store concepts. Finally, ownership alliances involve joint and cross-investment of major retailers. 


\subsubsection{Specialisation and diversification}

44. Retail stores have specialised and diversified in new areas and formats (EC, 1993). Recent analysis at McKinsey distinguished three stages in the development of the retail sector (McKinsey, 1995). Initially, the retail sector is made up of stores that supply an untargeted range of goods to a variety of customers on a small scale (stage 1). Typical stores in this formats are small convenience shops. Over time, and partly due to technological change, parts of the retail sector move to the second stage. Stores in this stage supply an untargeted range of goods on a large scale. They benefit from economies of scale and have substantial bargaining power in procurement. Department stores and hypermarkets are examples of such stores. In recent years, the retail sector has slowly moved to a third stage. Here, stores supply a more targeted range of goods on either a large or small scale. For instance, specialised large stores -- such as IKEA -- offer a single range of products but have almost everything related to that line of products. Such chains also offer a wide complementary range of services, such as after-sales services (e.g. Darty), extended opening hours and specialised product information and catalogues.

45. Smaller specialised chain stores, also fit into this third stage. A study by Burt and Dawson (1990) provides an overview of targeted small shops, all providing a different range of services to consumers. Discount stores (e.g. Aldi) target certain consumer groups requiring low prices; convenience stores (e.g. 7-Eleven) target consumers constrained by time; style (e.g. Benetton) and branded goods (e.g. Yves Rocher) shops offer products that value originality, exclusivity or brand reputation; specialist shops (e.g. Tie Rack) provide great choice in a narrow range of products; service shops (e.g. Mr Minit) provide extensive services as well as goods; while locality-specific shops (e.g. tourist shops) target consumers making impulsive decisions. Each of these shops has specific locational requirements, depending on the goods and services provided to consumers.

46. The three stages have quite different characteristics. This implies that, depending where a country is in its development of the retail sector, the retail sector may be quite different across the OECD area. The first format is usually the least productive and adds relatively little value to the goods it sells. Shops are small, choice is limited and little service is provided to the consumer. In the second stage, prices are lower, choice is larger, but few additional services are provided to consumers. Labour productivity, in terms of sales per employee, may be very high in this stage as a result of the exploitation of economies of scale. The third stage is characterised by higher and more targeted service. Labour productivity, measured by sales per employee, may be lower than in the second stage, but may be higher than in the second stage in terms of value added per employee (McKinsey, 1995). ${ }^{10}$

47. A related development is diversification ${ }^{11}$. As stores have increased in size, they have diversified their package of goods and services into non-specialised areas, often with higher margins. For instance, large food stores have incorporated many other items in their range. In addition, firms have considerably expanded the services they offer in addition to their traditional sales functions. A

10. This implies that countries with the most advanced retail sector do not necessarily have the highest level of labour productivity. Recent McKinsey work (McKinsey, 1995; 1996) makes adjustments for the difference in formats and still finds considerable differences in productivity. These results are discussed in Chapter 3.

11. Firms have also diversified in the type of enterprise (OECD, 1992). Modern retail systems include a wide range of retailing formats, often with considerable differences in the degree to which they are integrated with wholesalers and manufacturers. 
study on the US and French distribution sector (Gadrey, et al., 1990) shows the wide range of services offered in a typical US supermarket, such as home delivery, bagging, film processing and banking facilities, video rentals, pharmaceutical services, as well as several fresh food and take-out food services. French supermarkets were less developed in these areas, but the provision of foods such as bread, cheese and fresh produce was further developed than in US supermarkets. The number of products on offer has increased as well. A typical US supermarket had about 2,200 items on offer in 1950. By 1972 this had risen to about 9,000 and by 1995 a typical US supermarket had some 29,000 items on sale (OECD, 1997).

48. Diversification is also part of the competitive strategy of retailers, based on product differentiation and greater product variety (Dawson, 1995). It may also have been driven by technological changes, such as changing storage requirements and new cooking methods.

\subsubsection{Internationalisation}

49. Another major development is the internationalisation of retail chains and retail formats. To a large extent, internationalisation is based on foreign direct investment (mainly joint ventures, mergers and acquisitions), although there is some scope for cross-border shopping, mail-order ${ }^{12}$ and, as a new growth area, electronic shopping (OECD, 1997). Among European countries, internationalisation is limited to a number of large chains and a number of countries, mainly Germany, France, the United Kingdom, Belgium and the Netherlands (Table 2.9). To some extent, these are countries with relatively developed retail sectors, where firms seek opportunities abroad to expand their market. In terms of the share of FDI in retail GDP, the distribution sector is most internationally oriented in the Netherlands. Among the larger economies, Germany and the United Kingdom have the largest presence of foreign distributors. However, the leading retailers in most countries generally have domestic origins, and even for the most internationally oriented retailers, domestic business generally makes up the bulk of sales $(\mathrm{EC}, 1996)^{13}$.

50. Nevertheless, for large retailers, internationalisation has often become a necessity (Akehurst and Alexander, 1995). Internationalisation allows them to exploit new opportunities, both in terms of growth and new products and processes. As a result, successful retail formats, brands and concepts have spread over a wide range of countries. Internationalisation also allows large retailers to gather information and learn from techniques developed abroad. It also plays an increasing role in purchasing arrangements. Several large wholesale and retail chains have engaged in joint purchasing groups, that allow them to bring significant buying power to bear in their dealing with manufacturers. Within Europe, these groups were mainly established in the late 1980s and early 1990s. Co-operation in these groups may go beyond procurement and can also include marketing, logistics or finance (EC, 1994).

51. Internationalisation may be obstructed by domestic regulations (see Section 3). Successful retailing formats and strategies originating in a particular OECD country may not always be allowed

12. Among the countries of the European Community, mail order is most developed in Germany, where it had a market share of about 6 per cent in 1987. The large share of mail order in Germany is often linked to rather rigid restrictions on opening hours.

13. There are a few exceptions to this rule, such as Ikea and Toys 'R' Us in several countries, and a number of large food retailers in Spain, which are owned by French firms. 
under legislation in other OECD countries (EC, 1996). Differences in tastes and demand patterns also help to retain the local and domestic character of retailing in many countries.

\section{$2.4 \quad$ Technological developments}

52. Technological change has had an important impact on recent developments in the distribution sector. Both retail and wholesale enterprises try to achieve lower inventories, higher inventory turnover and faster receipt of goods (NRC, 1994; OECD, 1997). Enterprises also use technology to learn more about their customers and optimise sales efforts. Better information has for instance allowed firms to match inventories closer to customer needs and thus reduce the need for mark-downs and discount sales. It also has enabled stores to offer a wider range of goods (OECD, 1997). Technology has allowed more efficient links between manufacturers, wholesalers and retailers, particularly in inventory management. Other technological changes, such as scanning, have contributed to increased labour efficiency. Scanning has also contributed to a greater understanding of demand patterns.

53. Large enterprises, or enterprises engaged in co-operative arrangements, have been better able to profit from new technologies than small individual stores. For instance, Wal-Mart, the largest US -- and world-wide -- retailer, has been one of the main contributors to the development of inter-firm networks (OECD, 1997). Wal-Mart's investments in information technology have been credited with saving the firm up to $\$ 1$ billion a year, and have enabled it to reduce its distribution costs to only 3 per cent of sales -- as opposed to its rivals where these costs amount to 4.5-5 per cent of sales (OECD, 1997). These low margins partly arise because more than 90 per cent of all goods sold by Wal-Mart come directly from manufacturers ${ }^{14}$.

54. A recent study (Reardon, Hasty and Coe, 1996) finds that information technology has indeed contributed to increased productivity in retailing. The study estimates a production function for the retailing sector, based on data for 871 retail establishments in the Dallas-Fort Worth area, and finds that information technology is a productive factor in retailing. The study also found that these retail establishments did not yet use information technology to its full capacity, as the estimated marginal product of information technology substantially exceeded its marginal costs.

55. Small stores were initially slow to react to these developments, as investments in the development of new technologies were too expensive. Consequently, most of the innovations regarding products, processes and organisation were developed by large enterprises (OECD, 1992). However, imitation has proven to be relatively straightforward for many of these innovations, and property rights are not very secure. Many of the basic technologies have therefore diffused rapidly to small stores, presumably contributing to a relatively high social return on such innovations. However, electronic integration between firms remains costly and large firms are likely to be favoured by recent technological developments. Modern information technology is also undercutting the remaining advantages of small stores, such as variety, timeliness and tailoring to the individual, and may thus reinforce existing trends in concentration (OECD, 1997).

56. To some extent, technological developments have also contributed to the move from stage-1 to stage-3 formats, as discussed above. Information technology is an essential part in allowing firms

14. Although to some extent, information technology may have helped Wal-Mart to source its goods directly from manufacturers. 
to target specific customers and stage-3 stores use information technology in all parts of store management (McKinsey, 1995; Dawson, 1995). New information technologies, such as self-scanning and on-line shopping -- can also add greater convenience to shopping (OECD, 1997). Recent technological developments, such as the emergence of electronic commerce, have a considerable potential to radically change the distribution sector.

57. The diffusion of know-how in the retailing sector has been facilitated by several mechanisms (Kacker, 1988). Foreign direct investment has helped to diffuse modern technologies (and management concepts) to many countries. In addition, franchising has helped to spread technology and modern methods to smaller stores. Technology flows have also been helped by management contracts, joint ventures, and education and training programmes.

\subsection{Concluding remarks}

58. The discussion above shows that the distribution sector is dynamic and changing rapidly. Even though some parts have become highly concentrated, most of the sector is still characterised by small firms and ease of entry and exit (except when it is excessively regulated by governments, see Section 3). This suggests that the distribution sector is, in most respects, a structurally competitive industry. In addition, growing international competition may be undercutting some of the position of large firms in their domestic markets. This may help to enhance competition, even in relatively concentrated markets.

59. Where the sector is highly concentrated, or where market and technological trends are encouraging greater concentration, there may be a role for competition law enforcement. This may also be the case if increasing vertical integration between manufacturers and distributors leads to anticompetitive behaviour. This issue is discussed more extensively in the next section.

60. In analysing competition in the distribution, it is important to distinguish market segments. In some of these, competition is on price (e.g. mass food), in others on quality and service and in again others on an integrated package of goods and services. This difference in market structure implies that competition and other government policies towards the sector might need to be aware of these differences and thus be quite flexible. 


\section{Box 1: The Development of Electronic Commerce}

Electronic commerce between business and consumers is a rapidly developing area of economic activity (OECD, 1997a). Electronic commerce between firms, such as bank-to-bank fund transfers and electronic data exchange, are well established types of electronic transactions. Electronic commerce between business and consumers, such as on-line shopping, Internet shopping and on-line banking, are a more recent development.

Electronic commerce on the Internet is currently quite small, at about US\$ 500 million world-wide. However, most market researchers forecast significant growth of at least tenfold over the next three for four years, with the most optimistic forecast projecting a market of US\$ 780 billion in the year 2000. This would represent about 10 per cent of the total wholesale and retail market. Distance trade in general, which includes mail order, TV shopping, etc. is estimated at about US\$ 600 billion in 1994 and is expected to reach more than US\$2,000 billion in 2000.

Thus far, there is little research on the impact of electronic commerce on the distribution sector. In principle, entry barriers to electronic commerce are low and costs -- and thus prices -- are likely to be lower than in standard shops. Firms offering electronic services can substantially reduce costs, as they don't need physical outlets and may be less labour-intensive. The emergence of electronic commerce could significantly increase competition in segments of the distribution sector and could help to reduce consumer prices. It could also lead to the emergence of new activities, such as digital publishing and on-line advertising.

The further development of electronic commerce will require careful review, however. Some existing industry practices and regulations are not well geared towards electronic commerce. Various rules and systems for traditional transactions will also require review, e.g. authentication, privacy, consumer protection, payment, taxation and security. Many of these issues will need to be addressed at the international level, due to the cross-border nature of electronic commerce.

Not all parts of the distribution sector are likely to be affected by the same degree by the development of electronic commerce. Commercial activities with a high service content, or those selling fresh produce are likely to be less affected than those selling more standardised products. In any case, the development of electronic commerce may substantially change structure, conduct and performance in the distribution sector. 
Table 2.1: Contribution of the distribution sector to the economy

\begin{tabular}{|c|c|c|c|c|}
\hline & $\begin{array}{c}\text { Share of } \\
\text { distribution output } \\
\text { in total GDP, } 1993\end{array}$ & $\begin{array}{c}\text { Share of } \\
\text { distribution } \\
\text { employment in } \\
\text { total, } 1993\end{array}$ & $\begin{array}{l}\text { Share of retailing } \\
\text { employment in } \\
\text { total, } 1990\end{array}$ & $\begin{array}{l}\text { Share of enterprises } \\
\text { in distributive } \\
\text { trades in total, } 1990\end{array}$ \\
\hline United States & 15.7 & 15.5 & 11.4 & 17.9 \\
\hline Japan & 12.5 & 18.4 & 10.4 & 30.7 \\
\hline Germany & 7.8 & 11.3 & 8.3 & 28.0 \\
\hline France & 12.2 & 13.8 & 9.3 & 27.7 \\
\hline Italy $^{1}$ & 15.3 & 19.3 & 10.3 & 36.5 \\
\hline United Kingdom ${ }^{2}$ & 12.8 & 17.1 & 11.3 & 27.3 \\
\hline Canada & 10.0 & 16.4 & 10.4 & n.a. \\
\hline Australia & 17.9 & 20.8 & 13.1 & n.a. \\
\hline Austria & 12.8 & 14.4 & 7.5 & 30.5 \\
\hline Belgium $^{1}$ & 15.4 & 15.9 & 7.3 & 20.3 \\
\hline Czech Republic & 10.7 & 16.4 & 13.6 & n.a. \\
\hline Denmark & 10.7 & 10.8 & 7.8 & 19.4 \\
\hline Finland & 8.4 & 12.5 & 6.7 & 21.3 \\
\hline Greece & 9.6 & 15.5 & 9.3 & 40.0 \\
\hline Hungary & 10.8 & 12.4 & 11.5 & n.a. \\
\hline Iceland & 8.9 & 11.9 & 6.4 & 13.8 \\
\hline Ireland & 7.9 & 14.3 & 11.8 & 30.0 \\
\hline Korea $^{3}$ & 11.7 & 22.0 & n.a. & 39.8 \\
\hline Luxembourg & 13.5 & 15.9 & 9.7 & 29.8 \\
\hline Mexico $^{34}$ & 22.6 & 14.9 & n.a. & n.a. \\
\hline Netherlands & 12.7 & 16.2 & 12.3 & 26.7 \\
\hline New Zealand ${ }^{3}$ & 15.2 & 12.4 & 10.0 & n.a. \\
\hline Norway & 9.7 & 13.9 & 6.0 & 29.6 \\
\hline Poland & 8.9 & 16.4 & 5.2 & n.a. \\
\hline Portugal & 14.1 & 13.2 & 9.8 & 40.0 \\
\hline Spain $^{1}$ & 14.2 & 16.7 & 11.0 & 33.3 \\
\hline Sweden & 8.3 & 11.9 & 6.9 & 24.6 \\
\hline Switzerland $^{3}$ & 14.7 & 13.9 & 10.6 & 23.4 \\
\hline Turkey & 16.0 & 12.5 & 4.8 & n.a. \\
\hline
\end{tabular}

Notes: 1) Distribution GDP includes repair services. 2) Distribution GDP includes repair services, restaurants and hotels. 3) Distribution GDP includes restaurants and hotels. 4) Distribution employment covers salaried employment only.

Sources: Share of distribution in the economy based on OECD National Accounts, OECD (1996) and national sources. Retail employment from EC (1993a; 1994) and national sources. 
Table 2.2: Output, employment and productivity growth in the distribution sector, 1979-94

\begin{tabular}{|c|c|c|c|c|c|c|c|c|c|}
\hline & \multicolumn{3}{|c|}{ GDP growth } & \multicolumn{3}{|c|}{ Employment growth } & \multicolumn{3}{|c|}{ Labour productivity growth } \\
\hline & \begin{tabular}{|c|} 
Total \\
distribution \\
sector \\
\end{tabular} & $\begin{array}{c}\text { Wholesale } \\
\text { trade }\end{array}$ & Retail trade & \begin{tabular}{|c|} 
Total \\
distribution \\
sector \\
\end{tabular} & $\begin{array}{c}\text { Wholesale } \\
\text { trade }\end{array}$ & Retail trade & $\begin{array}{c}\text { Total } \\
\text { distribution } \\
\text { sector } \\
\end{array}$ & $\begin{array}{c}\text { Wholesale } \\
\text { trade }\end{array}$ & Retail trade \\
\hline United States $^{1}$ & 3.84 & 4.71 & 3.29 & 1.76 & 1.07 & 2.01 & 2.04 & 3.60 & 1.26 \\
\hline Japan & 4.74 & n.a. & n.a. & 0.58 & n.a. & n.a. & 4.14 & n.a. & n.a. \\
\hline Germany & 2.22 & 2.03 & 2.57 & 0.96 & 0.78 & 1.21 & 1.24 & 1.24 & 1.34 \\
\hline France & 1.84 & n.a. & n.a. & 0.18 & 0.04 & 0.27 & 1.65 & n.a. & n.a. \\
\hline Italy $^{2}$ & 2.47 & n.a. & n.a. & 1.46 & n.a. & n.a. & 1.00 & n.a. & n.a. \\
\hline United Kingdom $^{2}$ & 2.53 & n.a. & n.a. & 0.72 & n.a. & n.a. & 1.80 & n.a. & n.a. \\
\hline Canada & 2.86 & 4.55 & 1.56 & 1.51 & 2.33 & 1.19 & 1.33 & 2.18 & 0.36 \\
\hline Australia $^{2}$ & 1.94 & n.a. & n.a. & 1.97 & n.a. & n.a. & -0.02 & n.a. & n.a. \\
\hline Austria $^{3}$ & 3.13 & n.a. & n.a. & 1.31 & n.a. & n.a. & 1.80 & n.a. & n.a. \\
\hline Belgium $^{2}$ & 0.82 & n.a. & n.a. & -0.11 & n.a. & n.a. & 0.93 & n.a. & n.a. \\
\hline Czech Republic & n.a. & n.a. & n.a. & 3.13 & n.a. & n.a. & n.a. & n.a. & n.a. \\
\hline Denmark & 2.20 & 2.38 & 1.37 & -0.96 & 0.06 & -1.69 & 3.19 & 2.31 & 3.11 \\
\hline Finland $^{2}$ & 0.89 & 0.82 & 0.92 & -1.10 & -0.86 & -1.22 & 2.02 & 1.69 & 2.17 \\
\hline Greece $^{4}$ & 1.61 & n.a. & n.a. & 3.15 & n.a. & n.a. & -1.50 & n.a. & n.a. \\
\hline Iceland & n.a. & n.a. & n.a. & 1.51 & 2.49 & 0.87 & n.a. & n.a. & n.a. \\
\hline Ireland & n.a. & n.a. & n.a. & 1.70 & n.a. & n.a. & n.a. & n.a. & n.a. \\
\hline Korea $^{4}$ & 7.42 & n.a. & n.a. & 4.50 & n.a. & n.a. & 2.80 & n.a. & n.a. \\
\hline Luxembourg $^{2}$ & 3.46 & n.a. & n.a. & 1.40 & n.a. & n.a. & 2.02 & n.a. & n.a. \\
\hline Mexico $^{4}$ & 1.12 & n.a. & n.a. & 1.28 & n.a. & n.a. & -0.16 & n.a. & n.a. \\
\hline Netherlands & 3.42 & n.a. & n.a. & 1.61 & n.a. & n.a. & 1.79 & n.a. & n.a. \\
\hline Norway & n.a. & n.a. & n.a. & 0.40 & n.a. & n.a. & n.a. & n.a. & n.a. \\
\hline Portugal & 1.55 & n.a. & n.a. & 0.42 & n.a. & n.a. & 1.13 & n.a. & n.a. \\
\hline Spain $^{1}$ & 1.93 & n.a. & n.a. & 1.36 & n.a. & n.a. & 0.56 & n.a. & n.a. \\
\hline Sweden & 2.79 & n.a. & n.a. & -0.64 & n.a. & n.a. & 3.45 & n.a. & n.a. \\
\hline
\end{tabular}

Notes: 1) Distribution and retail trade include restaurants. 2) Distribution GDP includes repair services. 3) Includes machinery and equipment rental and leasing. 4) Distribution GDP includes restaurants and hotels.

Source: OECD (1996). 
Table 2.3: Characteristics of retail outlets and enterprises

\begin{tabular}{|c|c|c|c|c|c|}
\hline & $\begin{array}{l}\text { Number of retail } \\
\text { outlets, } 1990 \\
(1000 \text { s })\end{array}$ & $\begin{array}{c}\text { Retail outlets per } \\
10000 \text { inhabitants, } \\
1990\end{array}$ & $\begin{array}{l}\text { Employment per } \\
\text { retail outlet, } 1990\end{array}$ & $\begin{array}{c}\text { Employment per } \\
\text { retail enterprise, } \\
1990\end{array}$ & $\begin{array}{l}\text { Share of sole } \\
\text { propietorships in } \\
\text { total enterprises }\end{array}$ \\
\hline United States & 1,986 & 79 & 6.6 & 8.1 & 68.8 \\
\hline Japan & 1,631 & 132 & 4.2 & 5.3 & n.a. \\
\hline Germany & 537 & 85 & 4.4 & 5.4 & 81.5 \\
\hline France & 547 & 97 & 3.8 & 4.5 & 71.8 \\
\hline Italy & 986 & 171 & 2.4 & 2.6 & 90.4 \\
\hline United Kingdom & 465 & 81 & 6.5 & 8.7 & n.a. \\
\hline Canada & 157 & 55 & 8.6 & n.a. & 76.0 \\
\hline Australia & 154 & 90 & 6.7 & n.a. & n.a. \\
\hline Austria & 53 & 69 & 4.8 & 6.4 & 83.0 \\
\hline Belgium & 141 & 141 & 2.0 & 2.1 & 74.5 \\
\hline Czech Republic & 52 & 50 & 2.4 & n.a. & n.a. \\
\hline Denmark & 51 & 100 & 3.9 & 4.2 & 76.6 \\
\hline Finland & 38 & 77 & 4.1 & 6.2 & 41.9 \\
\hline Greece & 186 & 184 & 1.8 & 1.9 & 80.1 \\
\hline Hungary & 169 & 165 & 2.7 & n.a. & n.a. \\
\hline Iceland & 2 & 67 & 4.7 & 5.3 & 26.1 \\
\hline Ireland & 32 & 90 & 4.2 & 4.5 & 71.0 \\
\hline Korea & 717 & 166 & 2.0 & n.a. & 90.4 \\
\hline Luxembourg & 4 & 116 & 4.2 & 5.1 & 62.5 \\
\hline Netherlands & 120 & 80 & 5.3 & 6.7 & 70.1 \\
\hline New Zealand & 32 & 95 & 4.6 & n.a. & n.a. \\
\hline Norway & 39 & 92 & 3.2 & 3.2 & 18.0 \\
\hline Poland & 376 & 97 & 2.0 & n.a. & n.a. \\
\hline Portugal & 180 & 192 & 2.0 & 2.1 & n.a. \\
\hline Spain & 522 & 134 & 2.7 & 3.2 & 92.0 \\
\hline Sweden & 80 & 94 & 3.9 & 4.7 & 29.8 \\
\hline Switzerland & 56 & 83 & 6.8 & 7.7 & 70.6 \\
\hline
\end{tabular}

Sources: Retailing employment and number of retail outlets and enterprises from EC (1993a; 1994) and national sources. 
Table 2.4: Breakdown of retail enterprises by main sector of activity

\begin{tabular}{l|cccccc}
\hline & $\begin{array}{c}\text { Food, } \\
\text { beverages, } \\
\text { tobacco }\end{array}$ & $\begin{array}{c}\text { Clothing, } \\
\text { footwear }\end{array}$ & $\begin{array}{c}\text { Household } \\
\text { appliances }\end{array}$ & $\begin{array}{c}\text { Motor vehicles, } \\
\text { including fuel }\end{array}$ & Other Activities & Year \\
\hline & & & & & & \\
United States & 19.1 & 12.9 & 10.1 & 18.9 & 38.9 & 1993 \\
Japan & 39.1 & 9.6 & 9.9 & 10.4 & 30.9 & 1991 \\
Germany & 20.8 & 15.6 & 16.9 & 12.5 & 34.2 & 1992 \\
France & 26.1 & 19.0 & 11.2 & 15.3 & 28.4 & 1992 \\
Italy & 33.3 & 22.8 & 11.7 & 6.1 & 26.0 & 1991 \\
United Kingdom & 36.7 & 8.6 & 15.7 & 24.6 & 14.4 & 1992 \\
Canada & 25.5 & 18.3 & 11.7 & n.a. & 44.5 & 1993 \\
Australia & 28.9 & 16.2 & n.a. & n.a. & 54.9 & 1992 \\
Austria & 27.2 & 17.3 & 7.4 & 12.6 & 35.5 & 1994 \\
Belgium & 28.0 & 18.2 & 12.7 & 10.0 & 31.1 & 1988 \\
Denmark & 24.5 & 16.4 & 16.8 & 13.9 & 28.5 & 1992 \\
Finland & 24.3 & 13.4 & 10.2 & 13.1 & 39.1 & 1993 \\
Greece & 29.5 & 19.5 & 14.8 & 7.7 & 28.5 & 1988 \\
Iceland & 30.7 & 19.0 & 9.1 & n.a. & 41.2 & 1992 \\
Ireland & 54.0 & 9.0 & 4.4 & 11.5 & 21.0 & 1988 \\
Luxembourg & 23.8 & 18.8 & 15.6 & 15.5 & 26.4 & 1993 \\
Netherlands & 20.0 & 18.3 & 21.1 & 8.3 & 32.4 & 1994 \\
Norway & 29.2 & 16.3 & 8.3 & 12.1 & 34.1 & 1993 \\
Portugal & 39.7 & 18.8 & 7.4 & 5.5 & 28.6 & 1993 \\
Spain & 39.7 & 20.3 & 13.4 & 3.2 & 23.4 & 1988 \\
Sweden & 23.1 & 15.8 & 18.2 & 12.4 & 30.6 & 1993 \\
Switzerland & 25.6 & 13.4 & 5.4 & 5.6 & 50.0 & 1994 \\
\hline Sources EC & $296)$ & & & & \\
\hline
\end{tabular}

Sources: EC (1996) and national statistics. 
Table 2.5: Employment characteristics of retailing

\begin{tabular}{|c|c|c|c|c|}
\hline & $\begin{array}{c}\text { Total retail } \\
\text { employment } \\
\text { (1000 persons), } \\
1990 \\
\end{array}$ & $\begin{array}{c}\text { Share of female } \\
\text { workers in total, } \\
1990\end{array}$ & $\begin{array}{c}\text { Share of salaried } \\
\text { workers in total, } \\
1990\end{array}$ & $\begin{array}{c}\text { Share of part-time } \\
\text { workers in total, } \\
1990\end{array}$ \\
\hline United States & 13,092 & 47.2 & 92.6 & 33.5 \\
\hline Japan & 6,851 & 45.7 & 68.1 & n.a. \\
\hline Germany & 2,353 & 64.1 & 84.6 & 37.3 \\
\hline France & 2,090 & 50.3 & 74.1 & 25.3 \\
\hline Italy $^{1}$ & 2,401 & 35.6 & 38.7 & 6.4 \\
\hline United Kingdom & 3,030 & 58.1 & 84.2 & 40.7 \\
\hline Canada & 1,348 & 48.0 & 91.3 & n.a. \\
\hline Australia & 1,022 & 51.2 & 79.7 & 54.0 \\
\hline Austria & 256 & 64.4 & 83.6 & 13.0 \\
\hline Belgium & 275 & 52.8 & 52.4 & 17.4 \\
\hline Denmark & 200 & 52.8 & 84.0 & 38.3 \\
\hline Finland $^{2}$ & 157 & 64.4 & 82.7 & 11.6 \\
\hline Greece & 338 & 43.6 & 28.9 & 3.3 \\
\hline Iceland & 8 & n.a. & 89.9 & n.a. \\
\hline Ireland & 131 & 45.6 & 70.2 & 13.4 \\
\hline Korea $^{1}$ & 1,424 & 52.9 & n.a. & n.a. \\
\hline Luxembourg & 18 & 51.6 & 80.6 & 11.5 \\
\hline Netherlands & 638 & 56.7 & 79.1 & 47.3 \\
\hline New Zealand & 146 & 50.0 & 79.7 & n.a. \\
\hline Norway & 123 & 64.0 & 82.0 & 22.0 \\
\hline Portugal & 366 & 45.6 & 46.8 & 5.3 \\
\hline Spain & 1,434 & 53.7 & 46.6 & 6.4 \\
\hline Sweden & 314 & 60.5 & 82.8 & 37.3 \\
\hline Switzerland & 381 & 62.3 & n.a. & 35.9 \\
\hline
\end{tabular}

Notes: (1) Data for employment structure cover wholesale and retail trade.

(2) Data for part-time workers cover total distribution.

Sources: EC (1994), OECD (1996a) and national statistics. 
Table 2.6: Efficiency of the distribution sector

\begin{tabular}{|c|c|c|c|c|}
\hline & $\begin{array}{l}\text { Employment per } \\
\text { retail outlet, } 1990\end{array}$ & $\begin{array}{c}\text { Distribution GDP } \\
\text { per person engaged, } \\
1990(\mathrm{USA}=100)\end{array}$ & $\begin{array}{l}\text { Retail sales per } \\
\text { employee, } 1990 \\
(\mathrm{USA}=100)\end{array}$ & $\begin{array}{l}\text { Retail sales per } \\
\text { retail outlet, } 1990 \\
\quad(\mathrm{USA}=100)\end{array}$ \\
\hline United States & 6.6 & 100.0 & 100.0 & 100.0 \\
\hline Japan & 4.2 & 60.3 & 70.7 & 45.0 \\
\hline Germany & 4.4 & 78.5 & 100.7 & 66.9 \\
\hline France & 3.8 & 96.6 & 94.8 & 54.9 \\
\hline Italy & 2.4 & 95.3 & 72.3 & 26.7 \\
\hline United Kingdom & 6.5 & 59.5 & 77.6 & 76.7 \\
\hline Canada & 8.6 & 58.4 & 74.8 & 97.3 \\
\hline Australia & 6.7 & 59.4 & 60.1 & 60.6 \\
\hline Austria & 4.8 & 86.8 & 73.4 & 53.6 \\
\hline Belgium & 2.0 & 105.0 & 94.1 & 27.9 \\
\hline Denmark & 3.9 & 86.6 & 68.6 & 40.4 \\
\hline Finland & 4.1 & 56.4 & 85.9 & 53.4 \\
\hline Greece & 1.8 & 37.1 & 62.2 & 17.2 \\
\hline Iceland & 4.7 & 38.3 & 75.1 & 53.3 \\
\hline Ireland & 4.2 & 68.7 & 60.3 & 38.1 \\
\hline Luxembourg & 4.2 & 101.3 & 130.1 & 82.1 \\
\hline Netherlands & 5.3 & 95.2 & 54.8 & 44.3 \\
\hline New Zealand & 4.6 & 77.8 & 85.8 & 59.6 \\
\hline Norway & 3.2 & 42.3 & 92.9 & 44.6 \\
\hline Portugal & 2.0 & 45.4 & 52.8 & 16.3 \\
\hline Spain & 2.7 & 77.6 & 45.7 & 19.0 \\
\hline Sweden & 3.9 & 66.4 & 86.9 & 51.5 \\
\hline Switzerland & 6.8 & 115.8 & 78.8 & 81.7 \\
\hline
\end{tabular}

Source: First column from Table 2.1; Distribution GDP per person engaged based on conversion with 1990 PPP for expenditure on goods from OECD (1993); Retail sales based on EC (1993a; 1994) and national sources, converted to common currency with same PPP. 


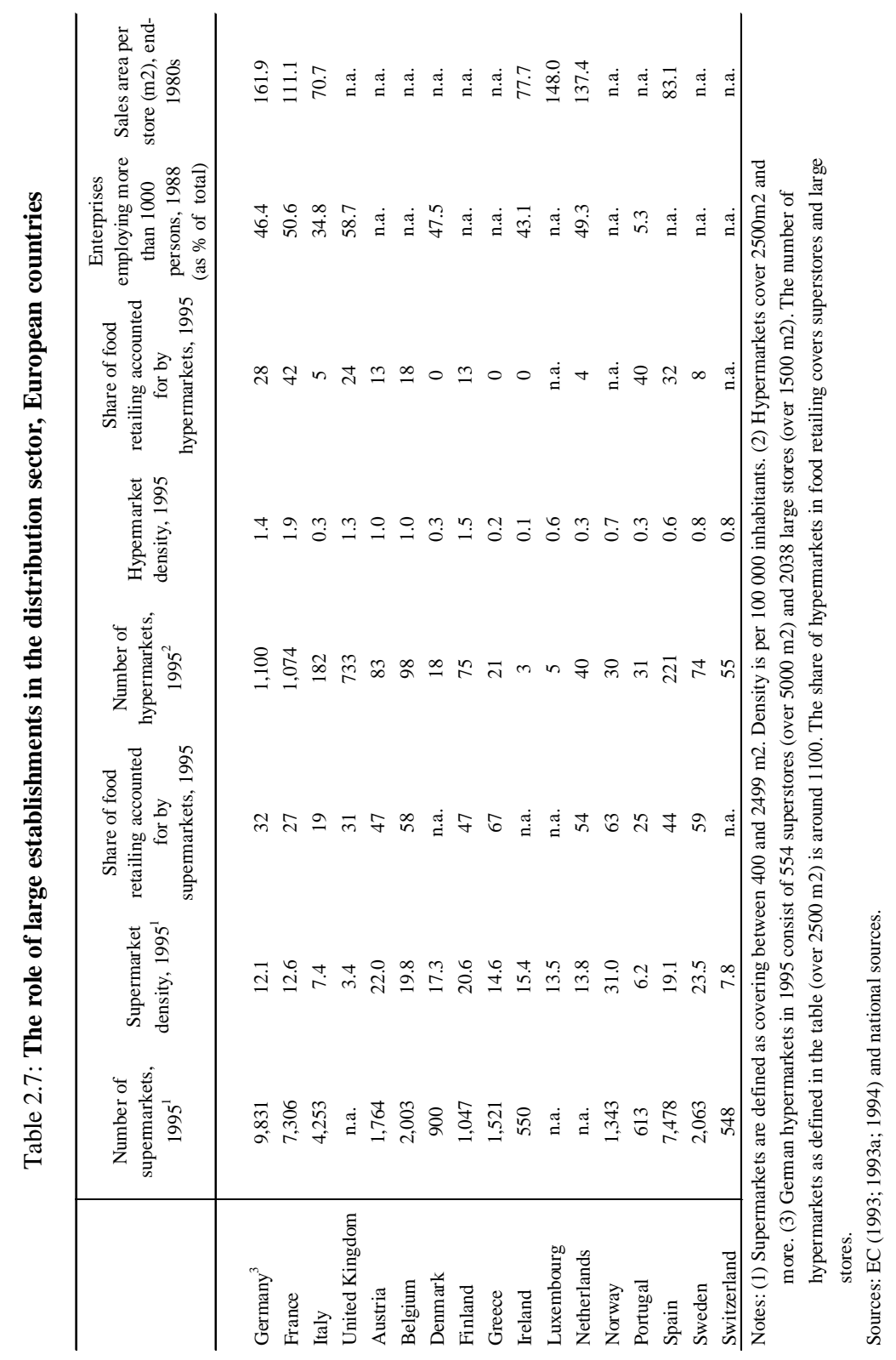




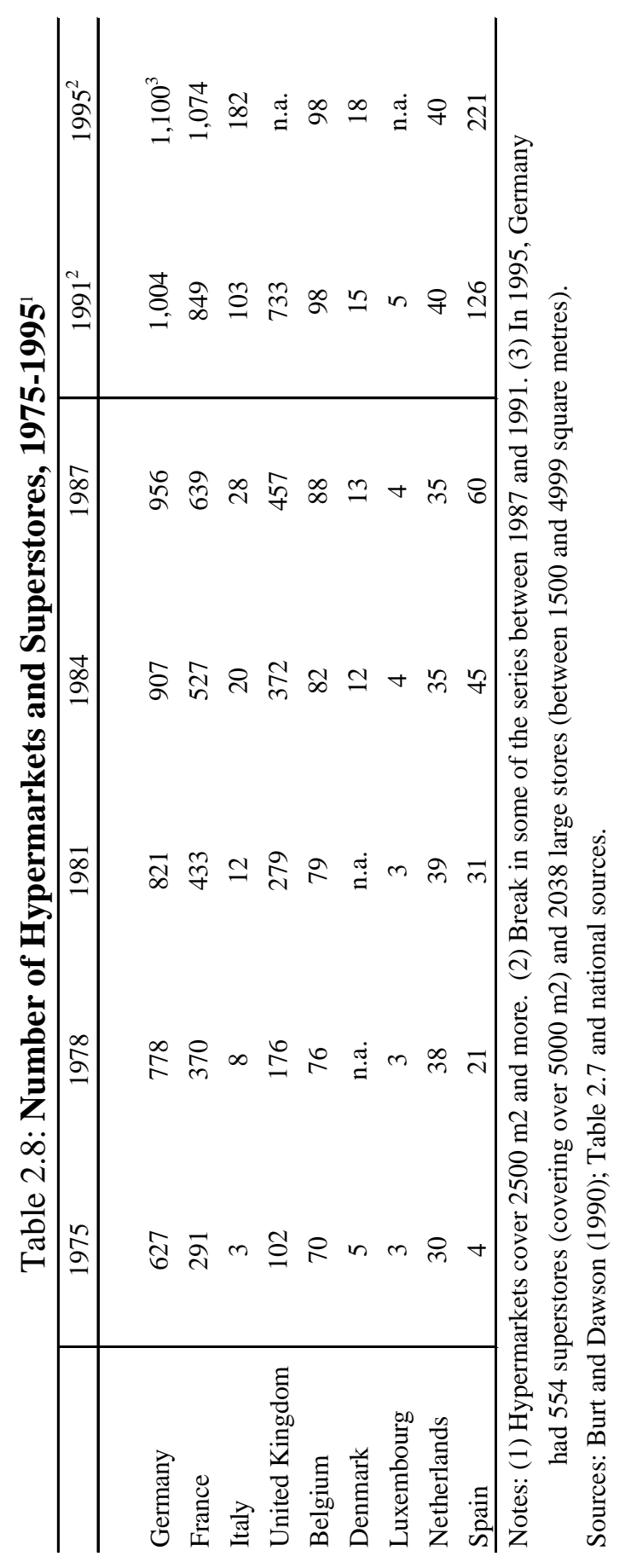




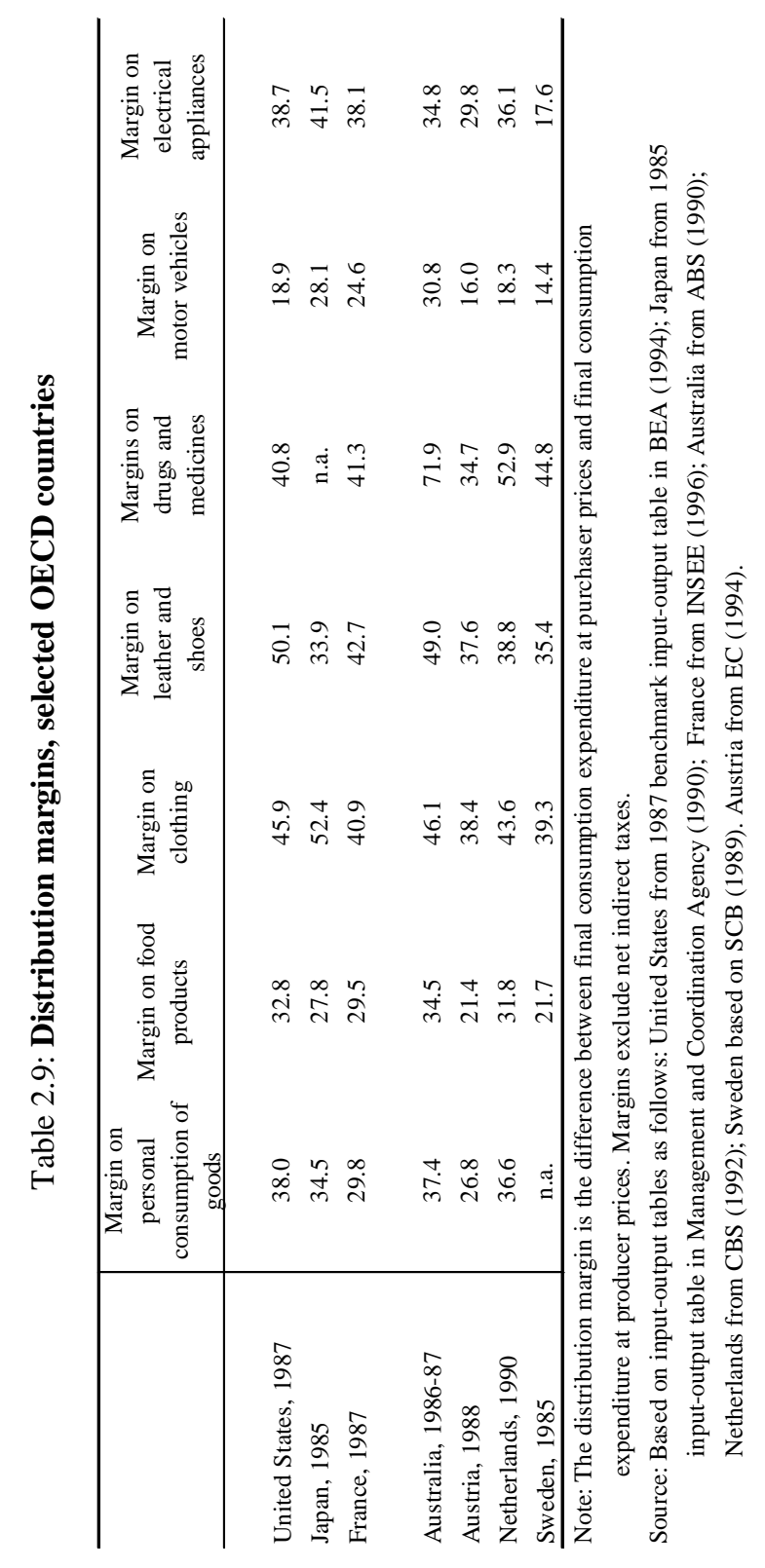

ก 


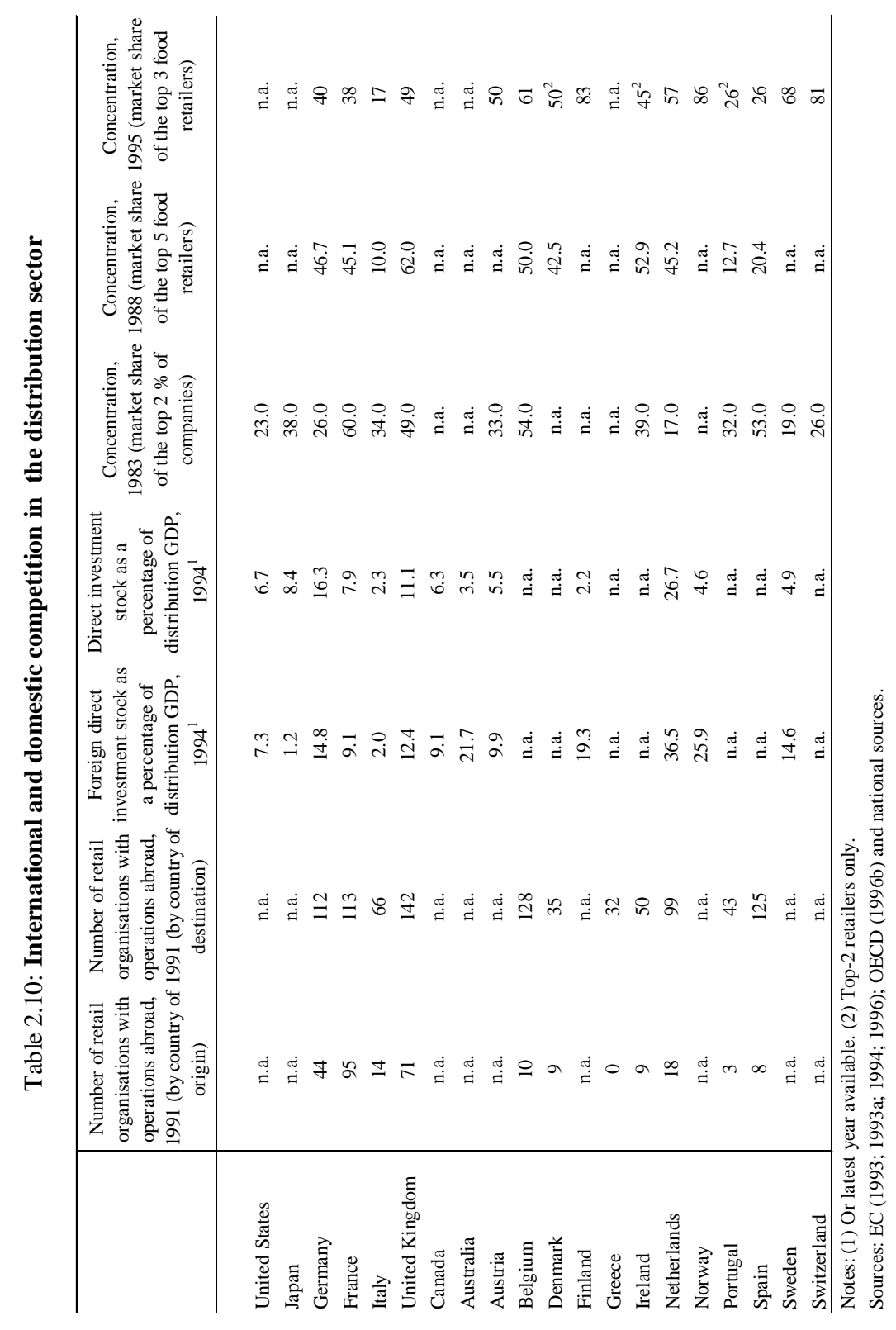


Figure 2.1 Productivity in the Distribution Sector ${ }^{1}$

(GDP per person employed, 1990=100)
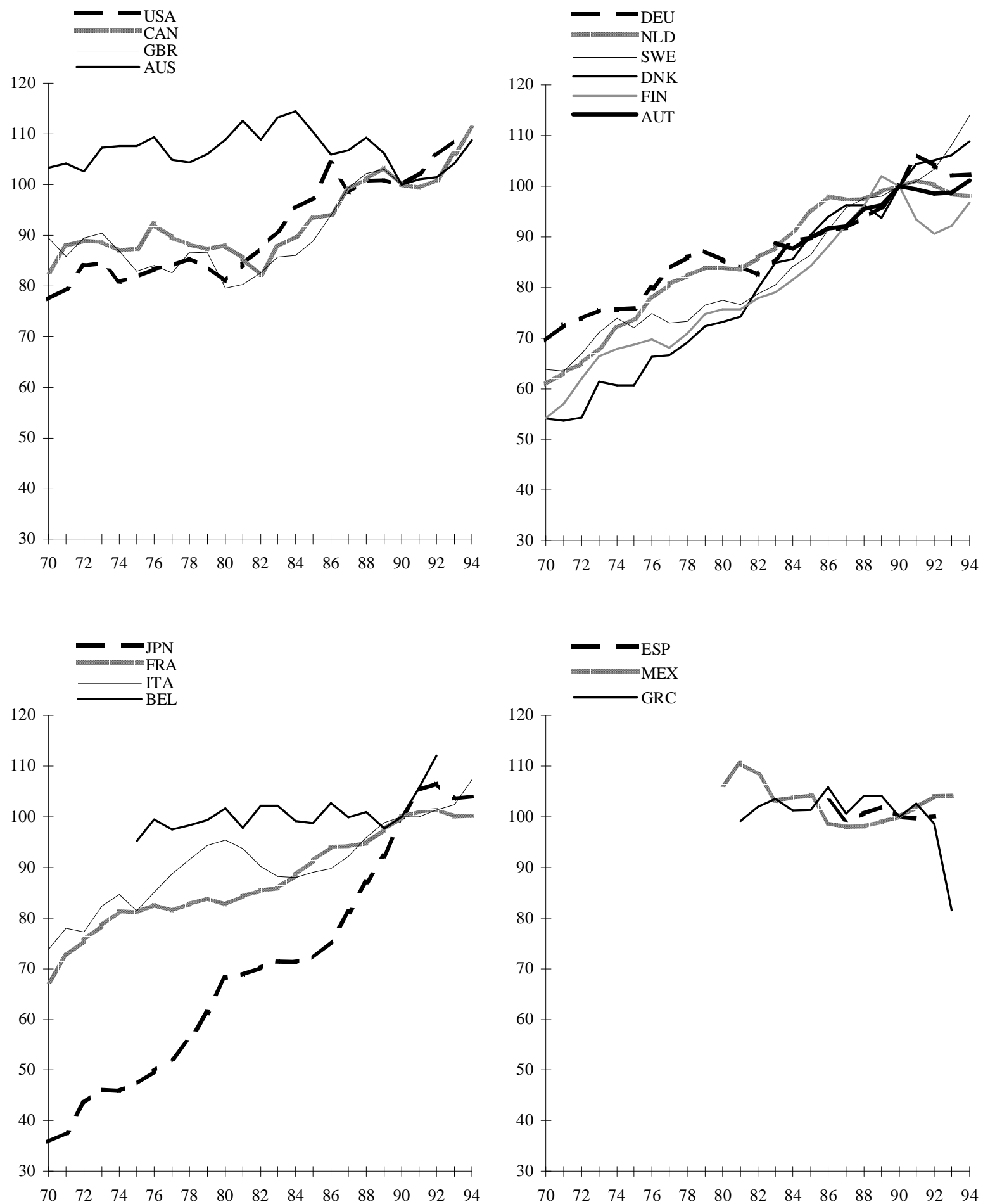

Source: OECD ISDB database

1. The definition of the distribution sector is not identical across the OECD. In some cases it includes restaurants and hotel. See table 2.1 and 2.2 for details. 


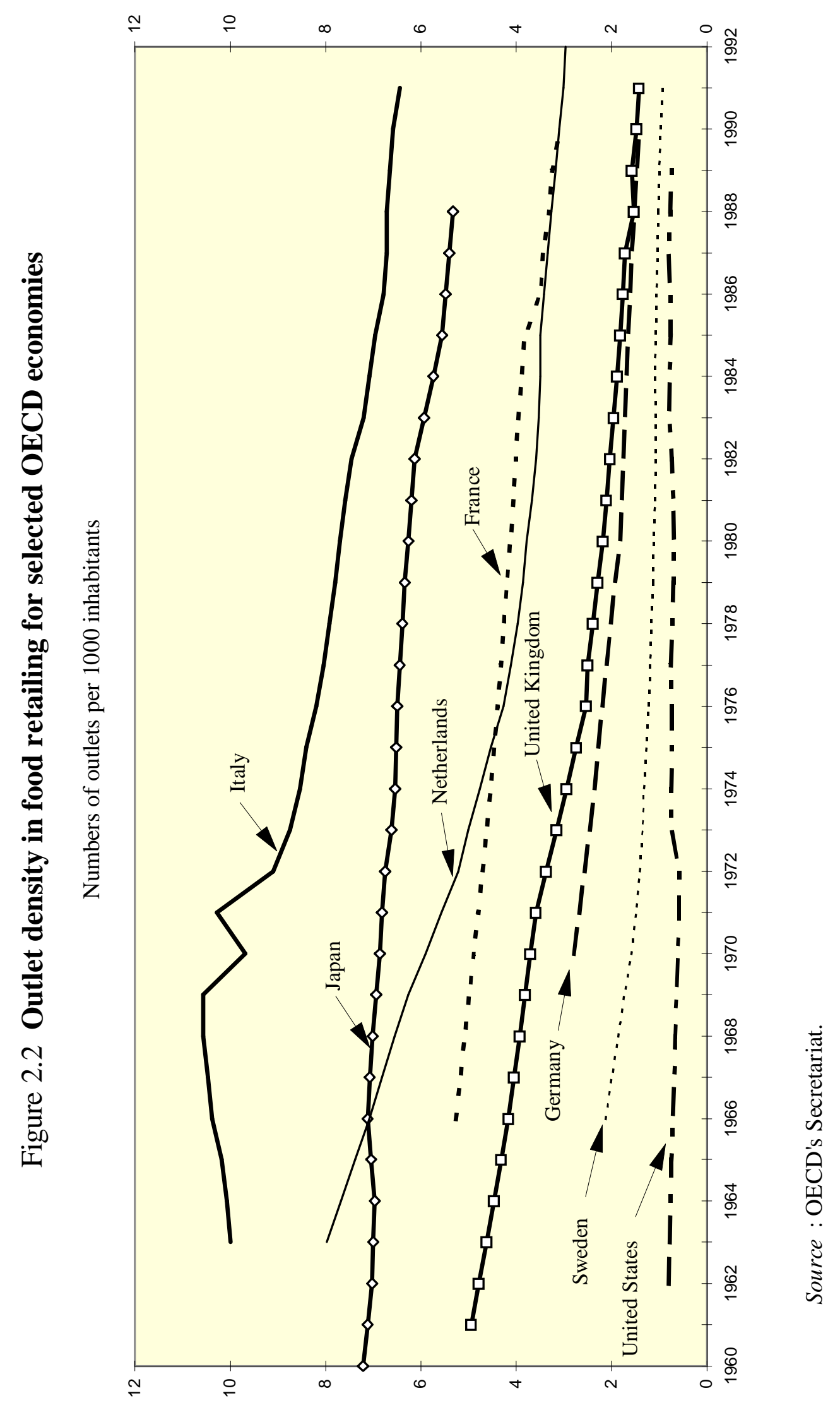




\section{How regulations affect the distribution sector}

\subsection{Introduction}

61. The distribution sector is affected by a wide range of regulations. Many of these are related to health and safety, others are related to urban planning and environmental issues, whereas some mainly have an economic basis. Many of the regulations in place protect non-economic values, because markets do not always properly value benefits that citizens may find important. Consequently, government intervention may be required in some cases. Nevertheless, regulations may be unduly restrictive, in which case they can drive up costs and ultimately prices, or they may, in some cases, reduce consumer choice.

62. To decide whether a case can be made for pertinent regulatory reform, it is necessary to assess in more detail whether and to what extent regulations affect performance, and whether policies can achieve the goals at which the original regulations were aimed in a less distortionary manner. Regulatory reform in the distribution sector aims at the design of regulations that are more narrowly targeted at achieving regulatory goals without unnecessarily interfering with firms' ability to perform their distribution function in an efficient manner.

63. Inefficiency resulting from poorly designed government regulations can increase costs both directly and indirectly. The direct costs increase occurs when the regulation prevents distributors from efficient conduct. Unduly restrictive regulations can also increase costs indirectly, by reducing competition. This occurs when the regulations make it harder for new firms to enter the market or for existing firms to compete on price or quality terms (including use of innovative means of distribution).

64. In some cases, if the costs of regulations clearly outweigh the benefits derived from them, a case can be made for the complete abolishment of regulations (deregulation). Even though social (health, safety, environmental) regulations may also have economic effects, the focus in this section is primarily on the effects of economic regulations, i.e. regulations that affect the ability of firms to enter a market, to set prices and to provide services. In some cases, competition policy rules are required to ensure that economic behaviour is competitive.

65. Many of the regulations that affect behaviour in the distribution are implemented and enforced at the local level. Reform of regulations in the distribution sector therefore encounters a problem of governance, as national governments can not always easily affect the relevant local and regional policies.

\subsection{The impact of regulations on performance: evidence from country-specific studies}

66. Many studies have looked at the impact of specific regulations on performance in the distribution sector, often with the objective to reform certain regulatory structures. Several types of regulations have been discussed in these studies, although two in particular have received attention, namely restrictions on large-scale outlets and on shop opening hours. Other regulations that have been the subject of reform or discussion include zoning and planning laws, legislation concerning vertical restraints, restrictions on pricing and promotion, as well as public monopolies on the sale of liquor, tobacco and pharmaceutical products. 


\subsubsection{The effects of limitations on large stores}

67. Several OECD countries, including Japan, France, Italy, Belgium and Spain, have specific national legislation aimed at the establishment of large-scale retail outlets. In some of these countries, incumbent retailers are involved in the implementation of such legislation and can sometimes block or slow down the establishment of large stores. Most other OECD countries also control the establishment of large stores, but this generally occurs in the context of local or regional planning.

68. Three concerns have generally given rise to the regulation of large stores. Firstly, an expansion of large stores could give rise to urban problems and environmental deterioration. Large stores are generally situated outside city centres. ${ }^{15}$ By being able to offer lower prices and a wider range of goods and services, they would draw consumers from the city centre and potentially threaten inner cities. This "in-town" - "out-of-town" debate is discussed below in the context of planning policies. Secondly, large stores often require access by private cars, as well as large surface areas, both leading to substantial impacts on the environment. Thirdly, restrictions on large stores have often been explicitly designed to protect small shops from competition, with the aim of saving employment in such shops.

69. Recent analysis at OECD (OECD, 1992; Høj, et al., 1996) suggests that restrictions on large outlets in Japan and Italy -- and, to a lesser degree, France -- have had a significant impact on the density of retail outlets in these countries. The outlet density in these countries is higher than could be expected given a range of structural characteristics for these countries (Table 3.3 below), implying that the average store-size in these countries is smaller than could be expected. As the average size of stores is closely linked to the efficiency of the distribution system (see Section 2), restrictions on large stores may thus have contributed to low productivity in the distribution sector.

70. Restrictions on large outlets may also have benefited those large stores that have been allowed to establish. If only few large stores are permitted, these stores face limited competition in their market and may thus be able to extract rents, for instance by charging higher prices. Given the conflicting views on the regulation of large stores, there has been a substantial political debate on this issue, particularly in Japan and France, but also in Italy, Belgium and Spain. A review of this debate forms part of the discussion that follows.

\section{Japan}

71. The main regulation concerning large stores in Japan is the Large-Scale Retail Store (LSRS) law (Daiten Ho). It was enacted in 1974, to replace an earlier law governing the establishment of department stores, and subsequently revised in 1979. Following the implementation of the 1979 law, the number of applications to open large stores fell from about 1600 in 1979 to some 300 in 1982 (OECD, 1995). The law thus proved quite effective in limiting the establishment of large stores.

72. The impact of the LSRS law has been investigated by a number of studies (Flath, 1990; Potjes, 1993; Nishimura and Tachibana, 1995; Riethmuller, 1996). These studies tried to explain why the Japanese distribution system remains so small-scale and fragmented, and have particularly focused

15. The original development of large stores "out-of-town" was often intended to reduce traffic congestion and enhance accessibility. Growing environmental concerns and urban deterioration have led some governments to reconsider this development. 
on the role of the LSRS law in this respect. The broad conclusion that has emerged from these studies is that the LSRS law has had a significant impact on the establishment of large stores and on the size and density of retail outlets. However, the LSRS law is not the most important explanation for the small average size of stores in Japan. Such explanations can be found in a range of factors, notably the lack of storage space in most households, limited ownership of private cars and high population density, which lead to frequent shopping close to home (Flath, 1990; OECD, 1995; Høj, et al., 1996; Flath, 1996).

73. In spite of these studies, the impacts of the liberalisation of the LSRS law have been substantial. During the early 1990s, the LSRS law was liberalised a number of times, the most recent being in May 1994. The latest revision substantially streamlined procedures to establish large stores, abolished regulations on store space for stores with less than 1,000 square metres, and allowed longer and more frequent opening hours of large stores. These revisions of the law have led to a rapid rise in the number of applications to open large stores of Category II (between 500 and 3,000 square metres in most areas and up to 6,000 square metres in the largest cities). Applications to open even larger stores (Category I) have not risen as much (Riethmuller, 1996). By 1995, the number of notifications was almost seven times that of 1982, which was the low point following the 1979 revision of the LSRS law (OECD, 1995). Currently, the number of new stores of over 500 square metres is increasing by almost 12 per cent a year.

74. The growth of large stores also appears to have a significant impact on the structure of the Japanese distribution sector. Between 1991 and 1994, the number of unincorporated enterprises fell by 11 per cent, whereas the number of incorporated enterprises grew by almost 2 per cent. Stores employing more than 20 people expanded by more than 20 per cent, and the average surface area of stores rose by 18.5 per cent (OECD, 1995). In addition, traditional "mom and pop" stores are disappearing and are often integrated in the larger convenience chains, such as 7 Eleven (Riethmuller, 1996). The number of large supermarkets appears to be increasing as well.

75. The successive liberalisations of the LSRS law in the 1990s coincided with a number of other structural changes in the Japanese distribution sector, the most important being the rapid growth of discount stores. In combination with an economic recession in the Japanese economy during this period, these structural changes have contributed to falling prices, increased variability in prices between different stores, and reduced costs of retail firms. Surveys by the Japanese Economic Planning Agency (Riethmuller, 1996) suggest considerable price differences between store types, with department stores and convenience stores quoting significantly higher prices than supermarkets and discount stores.

76. These structural changes also appear to have reduced the controls exerted by manufacturers on the price setting of retailers (OECD, 1995). In the past, manufacturers wished to standardise price setting across stores and often set prices to reflect the higher costs of small stores. Larger stores were not allowed to set lower prices but received volume rebates of special promotions for short periods. Currently, large retailing companies often negotiate directly with manufacturers. According to Riethmuller (1996), the only products by late-1994 for which prices were still fixed by manufacturers were books, some cosmetic products and medicines.

77. The changes over the past five years appear to have had a considerable effect on productivity and the costs of distribution in Japan. Relative to the overall change in prices, prices of distribution services (the GDP deflator for distribution) fell by about 2 per cent annually in both 1992 and 1993, contributing to a 0.1 to 0.2 per cent fall in the overall price level. In the five-year period following the first relaxation of the LSRS law, the real income gains to consumers have been estimated to be as 
large as $\$ 45$ billion (or 3/4 per cent of GDP; OECD, 1995). The Economic Planning Agency (EPA, 1996) has recently estimated that the deregulation of the LSRS law over the past years has created annual new demand of 4.7 trillion Yen (or about 1 per cent of total GDP).

78. Structural change also appears to have other beneficial effects to consumers. Modern supermarkets offer a much wider range of products than "mom and pop" stores -- industry sources suggest up to 8,000 food products alone. The time consumers need to shop may also decline as a result of the changing characteristics of the distribution sector, although this has changed only little thus far (Riethmuller, 1996).

\section{France}

79. In France, the establishment of large stores remains regulated by the Loi Royer, introduced in 1973, and subsequently tightened in 1991 and 1996. The current law (Loi Rafferin) gives the right to ad hoc local bodies to approve the establishment of shops with a surface over 300 square metres, i.e. all types of super- and hypermarkets ${ }^{16}$. The original law was passed under pressure of two special interest groups, namely small shop-owners and municipalities. The municipalities regarded large stores as a threat to local shopping centres, in which they often had substantial financial interests (Messerlin, 1993).

80. During the 1970s, the implementation of the Loi Royer limited the establishment of supermarkets, and particularly that of hypermarkets. However, as far as hypermarkets are concerned, the law was not as restrictive as might have been expected in the first instant (Burt, 1984). The number of hypermarkets opened fell substantially after the introduction of the law, from 62 in 1972 to less than 20 in 1975. However, general economic trends, including the effect of the 1973 oil crisis, may have been partly to blame. The growth of hypermarket presence in France continued during the 1970s, in spite of the Loi Royer.

81. During the 1980s, about one out of two applications to establish a hypermarket was accepted (Metton, 1995). Developers and retail firms soon started submitting more applications than required, in order to compensate for refusals, and also re-submitted refused applications. The law was also avoided in other ways. Many firms established large out-of-town shops by splitting up in adjoining units, each below the size limit. The law could also not limit the establishment of hard discount stores (Metton, 1995). These stores are generally smaller than hypermarkets, but offer lower prices for a more limited range of products. The establishment of these stores may have had similar impacts on some smaller shops as has the development of hypermarkets.

82. The Loi Royer was tightened further in 1990 (Loi Doubin), which led to a slowing in the construction of new outlets during 1991 and 1992. However, firms were increasingly responding to the legislation by expanding their existing hypermarkets. In fact, the overall surface area of hypermarkets has more than tripled since the implementation of the Loi Royer in 1973. From 1992 to 1996, the number of hypermarkets increased from 930 to 1,078, whereas the number of supermarkets increased from almost 7 thousand to almost 8 thousand over the same period. The law was again

16. Typically, these bodies consist of a number of locally elected officials and some representatives of trade and commercial interests. The revisions of the Loi Royer over the past years have reduced the number of persons representing trade and commercial interests in these bodies. 
tightened in October 1996 (Loi Raffarin) and permission to establish a new store is now required for all stores over 300 square metres.

83. The Loi Royer and its tightening over time appear to have failed in the objective to limit hypermarket presence in the French retail sector. The density of large stores, and hypermarkets in particular, is relatively high in France, as is average productivity of the retail sector (Section 2). Hypermarkets and other large-surface formats control a significant part of the retail market. In 1996, hypermarkets and supermarkets controlled some 84 per cent of French food retailing, which is substantially higher than in most other European countries.

84. The main effect of the Loi Royer may actually have been in another area (McKinsey, 1997), as it appears to have slowed down the development of in-town commercial shopping centres. Such centres are focused around department stores or speciality chains (IKEA, etc.), but also include a wide range of smaller shops. The introduction of the Loi Royer appears to coincide with a slowdown in the establishment of such in-town commercial centres, but it has not slowed down the establishment of out-of-town commercial areas, most of which focus on hypermarkets (McKinsey, 1997).

85. The restrictions on large stores have therefore limited structural change in the French distribution sector, and particularly the development of the most modern retail formats, such as speciality chains. However, the law has been much less restrictive where hypermarkets and supermarkets are concerned, certainly in comparison with some other countries, such as Japan and Italy. The legislation may have led to an artificial increase in the costs (and thus prices) of services provided by super- and hypermarkets. Anecdotal evidence suggests that planning procedures were quite slow and that retail chains took very long to realise their development plans (McKinsey, 1997).

86. The law also gives a substantial advantage to existing large stores, as they control relatively scarce and highly priced assets. In favouring incumbent firms, the law is also likely to favour domestic firms over foreign investors (Messerlin, 1993; McKinsey, 1997). Thus, on balance in France large store restrictions have placed an additional burden on the retail sector, and may have reduced the potential benefits to consumers of large stores, commercial shopping centres and speciality chains.

\section{Italy}

87. Entry of large stores in Italy is regulated by law no. 426, enacted in 1971 (Pellegrini and Cardani, 1993; Pellegrini, 1995). The law was intended to slow down structural change in the distribution sector and reduce the social tensions that might result from the rapid entry of large stores (Pelligrini, 1995). Priority was given to existing store owners who wished to modernise and expand their own stores. Law 426/71 allowed each municipality to set the degree of liberalisation acceptable to local conditions, a situation which allowed significant lobbying by special interest groups and particularly by local shop-keepers themselves.

88. Law 426/71 has slowed down the diffusion of large stores, particularly in food retailing. By allowing differentiation across regions, the law has also had different implications from one region to another. For instance, hypermarkets have spread much less in Southern Italy than in the other parts of the country (EC, 1993; Pelligrini, 1995). The Law has favoured local stores and co-operative arrangements based on local stores, such as buying groups and voluntary chains, as such groups were generally better able to overcome local resistance to expansion. Hence, co-operative chains have gained significant market share relative to firms with multiple outlets. The result is that the most 
efficient store formats have not been able to expand. Thus, restrictions on large stores have slowed down the development of large retail organisations in Italy, and reduced the internationalisation process of the retailing sector.

89. The implementation of Law 426/71 has not always been very strict. Implementation was quite strict during the 1970s, when social unrest and high unemployment favoured the protection of small shops and employment in these shops (Pellegrini and Cardani, 1993). However, implementation became more relaxed during the 1980s, as higher growth permitted more rapid structural change and reduced the lobbying strength of small-store owners. The reduced importance of small stores has also given municipalities greater incentives to favour large stores, which has accelerated the transformation of the sector a little. The law has also been changed somewhat over time (Pelligrini, 1995). Various amendments have given retailers some room to upgrade existing stores and expand them somewhat.

90. As in other countries, the barriers to entry imposed by Law 426/71 have had some effects on competitive developments in the distribution sector, particularly in food retailing. They have changed the mix of services available to consumers, rationed the supply of some services, reduced consumer's welfare and provided rents to incumbent stores, in particular to large ones (Pellegrini and Cardani, 1993).

91. Large stores that have been allowed to establish, have also not done as well as might be expected. They often had to be satisfied with stores of sub-optimal size, in second-best locations, and were also not able to achieve logistic efficiency. The potential benefits of the presence of large stores have thus been more limited than could be expected a priori. Currently, however, existing large retailers seem not very keen to change the law (Pelligrini, 1995). They see the complex establishment procedures as an effective entry barrier to competitors, particularly from abroad.

92. The Italian monopoly commission has studied the effects of Law 426/71 on competition and has argued for the liberalisation of entry rules to the sector, essentially by asking for the abolition of Law 426/71 (Pellegrini, 1995). Its report was received unfavourably by almost retail organisations, including those of larger firms. Larger firms argue that liberalisation would be to the advantage of foreign competitors, as these have not been limited as much by restrictive regulations. They therefore have more resources to invest and would be able to take advantage of economies of scale.

93. Restrictions on large stores, in particular hypermarkets and specialised stores, remain very rigid. Several regional development authorities have explicitly stated their opposition to the development of free-standing large stores and to the development of retail parks. The argument is often that the development of such parks would seriously threaten city centres of medium-sized towns and have environmental consequences.

\section{Belgium}

94. Between 1937 and 1961, large stores in Belgium were restricted under the "Padlock law". This law proved to constrain modernisation of the retail sector and was therefore repealed in 1961 . The abolition of this law led to a rapid modernisation of the Belgian retail sector and a substantial expansion in the number of hypermarkets and supermarkets. However, small retailers felt severely pressured by the growth of large-scale outlets and demanded tighter restrictions (François and Leunis, 
1991). Subsequently, the Belgian government introduced the 1975 Business Premises Act (Loi Cadenas or Second Padlock Law), which was aimed at regulating the establishment of large stores.

95. The introduction of the Second Padlock Law had substantial impacts on the transformation of the Belgian retail sector. The total number of supermarkets continued to grow, but the rate of expansion was substantially lower than before 1975. Hypermarkets were particularly affected and only 8 opened between 1975 and 1992 (François and Leunis, 1991; Mérenne-Schoumaker, 1995). The number of large supermarkets (over 1500 square metres) rose rapidly since the introduction of the Loi Cadenas, however, possibly because they substituted for hypermarkets.

96. These regulations remain in place (OECD, 1997b). Anyone intending to establish or modify a retail store has to file a "socio-economic request" to obtain permission. Small shops below a certain surface limit are exempted. The procedure is as follows (OECD, 1997b). The Comité socio-économique pour la distribution -- a committee whose membership includes civil servants representing the various ministerial departments, and a regional representative -- takes an initial decision about filed requests and reports it. Both the person who filed the request and the members of the Commission nationale pour la distribution -- a committee in which consumers, employers, retailers and wholesalers are represented -- can appeal this initial decision. It is the same Commission nationale pour la distribution that treats the appeal and reports its opinion to the Comité interministériel. Finally, the Comité interministériel takes a decision based on these two reports (Ministère des Affaires Economiques de Belgique, 1988). As in a number of other countries, the legislation allows a considerable role for local shopkeepers, and these can influence the application of the rules and thus restrict entry of new stores.

97. Since mid-1994, this legislation has been made more restrictive in two ways. First, the threshold surface level has been reduced by 33 to 50 per cent, depending on the zone in which the retailer seeks to establish. In addition, the number of requests accepted as a percentage of all requests has dropped from 90 per cent in 1992 to 72 per cent in 1995. The strengthening of the regulations appears a response to an increase in circumvention of the rules. Shop-owners increasingly created two stores, side-by-side, both just below the authorisation threshold.

98. The legislation on large stores appears to have significantly slowed down structural change in the Belgian distribution sector. Consequently, the average size of shops in the country is significantly smaller than in surrounding countries (Section 2). The legislation appears also to have contributed to the rapid internationalisation of the major retailers in Belgium, GIB and Delhaize (EC, 1996a), since these companies were blocked in their domestic expansion plans due to the 1975 legislation. It may also have contributed to the rapid development of franchising in Belgium, as the large retailers used this strategy to circumvent the legislation and expand their sales (EC, 1996a).

\section{Spain}

99. Entry of retail outlets is constrained by relatively tight zoning laws at the local level, implemented by municipal authorities (McKinsey, 1994; EC, 1996a; Cabrera, 1995). Authorisation under these laws appears to have been linked to the provision of other services and the authorisation process was quite lengthy and complex. Until recently, there were few limits as regards the size of stores. The relatively liberal stance with regards to large stores has led to a rapid modernisation of the Spanish retail sector, and to a rapid entry of foreign, particularly French, retail chains. 
100. The first hypermarket was established in 1973 and by 1991 , the number had risen to 126 , with an average sales area of over 7000 square metres (EC, 1993). The density of very large stores -such as hypermarkets and larger supermarkets -- remains, however, relatively low in Spain, reflecting a low starting point. The typical store only had about 80 square metres by the end of the 1980s, compared with 160 square metres in Germany and 110 square metres in France (Section 2). There is some regional variation in the density of outlets, as most of the original establishments focused on areas with high population density or high incomes. At the beginning of 1996, Spain introduced specific legislation to restrict the establishment of large stores (EC, 1996a).

101. The Spanish distribution sector is not yet as developed as it is in some of its European counterparts, such as Germany, France and the United Kingdom. This is partly a reflection of the low starting point of retailing in Spain. The retail segment remains characterised by many small stores and in 1990, more than 90 per cent of all stores were individually owned (EC, 1993). Concentration is relatively low, even in the food segment of the market, although the trend is towards increased concentration and a rising share of hypermarkets and supermarkets in the food segment. By 1991, four major companies (Pryca, Cecotinsa, Alcampo and Hipercor) controlled almost 80 per cent of the hypermarket segment of the retail market. Three of these companies were owned by major French distribution chains (Carrefour, Promedes and Auchan). The major retail company in Spain (El Corte Inglés) is Spanish-owned.

102. Estimates made by McKinsey (1995) indicate that labour productivity -- measured as value added per employee converted at PPP -- in the Spanish general merchandise retailing sector is almost 30 per cent below the US level and around 15 per cent below France. These estimates are confirmed by the estimates reported in Section 2. To some extent, the low level of labour productivity appears to reflect the low share of supermarkets and hypermarkets.

\section{Concluding remarks}

103. Although there is a wide range of studies on the impact of large-scale restrictions, there have been few empirical assessments of their impact on performance in the retail sector. The main exception are the studies that have been made for Japan, several of whom suggest substantial effects of the liberalisation of restrictions on large stores. However, even though the empirical evidence is somewhat limited, most studies on these regulations reach a similar set of (qualitative) conclusions:

- the restrictions have retarded structural change in the retail sector in most countries that have special restrictions, and have often also limited the efficiency of those large-scale stores that were allowed to establish;

- they have tended to favour existing stores and sometimes provided them with substantial rents. Large stores that were able to establish have benefited in particular, as they were confronted with limited competition in their segment of the market;

- restrictions on large stores have reduced the potential gains to consumer welfare from larger outlets, by limiting the expansion of consumer choice.

- regulations on large stores may have reduced innovative effects (OECD, 1997), and slowed down the development of modern retail formats (McKinsey, 1997). Large 
retailers have often taken the lead in developing and implementing new technologies, such as scanning and integrated inventory management.

104. Restrictions on large stores therefore appear to have had some economic side effects, some of which may be quite costly. The main issue in reforming such regulations is whether the policy goals at which these restrictions are aimed can be achieved in a less distortionary and more efficient way. The most important of these goals are the protection of employment and the protection of urban centres and the environment.

105. These policy goals may not be best served by the existing regulations and could possibly be reached in a less distortionary manner. Protecting small shops from large-scale outlets to save employment may not be needed. The developments over the past decades (see Section 2) suggest that small shops continue to have an important place in advanced retail systems, particularly outside the mass food market. Small shops are increasingly becoming more specialised and customer-oriented. In addition, they are increasingly finding ways to remain competitive relative to large stores, for instance by engaging in co-operative arrangements, such as franchising, that allow them to reduce costs and achieve economies of scale. Many of them also find their own specialised "niche" in the market (Logan, 1994). However, small supermarkets and general food stores are likely to disappear due to competition from larger outlets (and small speciality stores), but this process is unlikely to affect overall retail employment.

106. Indeed, modern retail formats are quite labour-intensive. Large stores often need significant threshold labour, in particular if they are open during the evening and on Sundays, or if they are service-oriented, and are therefore quite labour-intensive compared with traditional supermarkets or hypermarkets. Small speciality stores are often highly service-oriented and also require a high level of staffing. Thus, the US distribution sector, arguably among the most advanced in the world, has continued to show rapid employment growth over the past 15 years (Section 2; McKinsey, 1997). Furthermore, the liberalisation of the LSRS law in Japan over the past 5 years appears not to have led to significant employment losses. More importantly, analysis at OECD in the context of the OECD Jobs Study (OECD, 1994) suggest that slowing down adjustment by engaging in protectionist measures, whether internationally or domestically, is not the best answer to employment and unemployment concerns.

107. Nevertheless, the liberalisation of restrictions on large stores could potentially lead to a significant restructuring of the sector. Many traditional small shops would disappear and workers in these jobs would lose their jobs. However, experience in several countries suggests that many jobs would also emerge in new retail formats and more specialised stores. In fact, employment in the distribution sector has continued to grow over the past decades in almost every OECD country, notwithstanding substantial productivity gains.

108. Recent trends suggest, however, that most European countries are strengthening their restrictions on large stores. France, Italy and Belgium have all recently made their laws more restrictive and Spain introduced legislation limiting large-scale outlets in the first half of 1996. Portugal, despite having given permission to some fifteen hypermarkets and three out-of-town shopping centres, used exceptional power to stop construction (Davies, 1995). To some extent, the tightening of regulations in these countries may reflect the unease about the possible employment consequences of liberal legislation on large stores in an environment of high unemployment in these countries. Among the countries that have specific legislation on large stores, Japan is the only where the trend seems to be towards less regulation. 
109. The other goal at which restrictions on large stores were aimed, urban and environmental protection, is also an important policy goal, but one that could possibly be achieved in a different way. In principle, concerns arising from non-economic goals could be integrated in local and regional planning. If a special (national) legislation exists, separate from local and urban planning rules, it is likely to be used, often with the explicit aim to reduce competition in the distribution sector (OECD, 1992). Giving established retailers a say in the actual implementation of such legislation, as is the case in a few countries, makes this even more likely. Local and urban planning (zoning) laws are further discussed below.

110. In moving the responsibility for planning policies to the local or regional level, care will have to be taken in avoiding anti-competitive conduct. Local authorities are often more influenced by local lobby groups, and therefore more likely to control entry of new (and foreign) entrants. The Italian experience on this point illustrates the need for caution. To some extent, competition authorities may help to limit such behaviour.

\subsubsection{The regulation of shop opening hours}

111. Shop opening hours have recently been on the political agenda in several OECD countries, particularly in Europe. Over the past few years, Germany, Denmark, Greece, the Netherlands and the United Kingdom all liberalised regulations on shop opening hours, which were previously rather restricted, while Austria liberalised its opening hours as of the 1st of January 1997. In Japan, opening hours for large stores were relaxed in the 1994 deregulation of the LSRS law.

112. The pressure for more flexible opening hours mainly arises from a view that short opening hours reduce consumer welfare and are in conflict with a general demand for more flexible working hour arrangements. This demand arises partly due to greater diversity in working hours in the economy as a whole, as well as the higher participation of women in the labour force. In some cases, for instance Austria, this consumer demand led to an increase in cross-border shopping, to countries where hours were more liberal. To some extent, the increase in border-shopping has sped up the deregulation in Austria ${ }^{17}$. These instances demonstrate the anti-consumer impact of preventing firms from being open when their potential customers want or need to shop.

113. The initial regulation of opening hours was mostly intended to create a common -sometimes religious -- pause day (often Sunday) and to prevent employees from being forced to work excessive hours. Even though they were originally not explicitly designed for this purpose, regulations on opening hours tend to favour small stores over large ones. ${ }^{18}$ Small stores tend to have greater difficulties in expanding opening hours, due to the need to employ a certain "threshold" labour at all times (Nooteboom, 1983). ${ }^{19}$

17. Deregulation may also be affected by more people becoming aware of retail systems in other OECD Member states and the regulatory arrangements in place in those countries (Matthews and Mayes, 1994).

18. Hours restrictions may also favour small stores if the legislation is poorly enforced. Small stores may better be able to avoid prosecution than large stores.

19. This may be less so for small family stores that may use family workers for these hours. 
114. Currently, regulations on opening hours differ substantially across the OECD area (Table 3.1; EC, 1996a). In a number of countries, opening hours are completely free, although local authorities (states or municipalities) can often introduce some restrictions. In other countries, opening and closing hours are tightly regulated and limits are imposed on the total weekly opening hours of shops.

115. The absence of legal restrictions in some countries does not necessarily imply that shops are also open for a longer period. For instance, even though restrictions on opening hours in Spain are relatively mild, shops are open for only 46 hours a week on average (Table 3.1). However, the absence of restrictions in Spain and other OECD countries generally implies more flexibility and greater variability in opening hours, as it enables stores to align their opening hours with consumer demand. In some cases, actual opening hours may also be limited by working hour regulations, arising from labour legislation.

116. Due to the recent policy debate on this issue in a number of countries, there have been several studies on the liberalisation of opening hours. Some of these are based on an assessment of actual effects (Civildepartement, 1991; Lanoie, et al., 1994; Tanguay, et al., 1995), while others refer to planned measures (Cette, et al., 1992; Ifo Institute, 1995; CPB, 1995; EIM, 1995). The 1974 deregulation of opening hours in Sweden has been evaluated quite extensively (Box 2). Careful and quite elaborate studies have also been made for Germany and the Netherlands (Box 3). What emerges from these studies is the following:

- Consumer welfare is markedly enhanced when opening hours are liberalised. Longer hours allow consumers more time to make their choice and thus enhances the "entertainment" value of shopping (EC, 1996a). The experience in the Netherlands suggests that consumers spend more in the evening than during the day for a given shopping objective. Opening hours are likely to be expanded particularly in those areas where consumers require it.

- Average prices may increase marginally, as higher labour costs resulting from increased threshold labour (Nooteboom, 1983), may not be fully compensated by lower capital costs, due to higher capital utilisation. Evidence from the 1990 liberalisation of opening hours in Quebec suggests that mark-ups may increase and that rebates may be reduced (Lanoie, et al., 1994; Tanguay, et al., 1995). The evidence from Sweden suggests that prices fell marginally following liberalisation. ${ }^{20}$

- The employment effects of longer opening hours are unequivocally positive, mainly due to an increase in threshold labour, but possibly also as the result of increased sales.

- Sales of the distribution sector increase a little. The combined effect of higher employment and only slightly higher sales could lead to a slight reduction in labour productivity, since labour may be less efficiently utilised. The experience in Sweden was that productivity increased, since sales rose substantially more than employment.

20. In the United States, automobile dealers in one large urban area agreed to uniform, restricted opening hours in order to reduce the possibility of consumers engaging in comparative shopping, and thus allowing these firms to raise prices. The US competition authorities judged the agreement to be a restriction of competition, although it found no evidence on whether the agreement had succeeded in raising prices. 
Partly, this effect may also be due to the replacement of small stores by large stores following the liberalisation of opening hours (see below).

- Liberal opening hours strengthen the position of large firms, as these are generally better able to respond to longer opening times. Some small shops (e.g. convenience stores) may gain, but the majority will lose market share against larger shops. This is particularly likely in the food segment of the market, where smaller supermarkets and general food stores are likely to lose market share.

- The response to reform of legal opening hours is greatest in the food segment of the retail sector. Other segments where opening hours may be lengthened are furniture and clothing shops.

- More liberal hours may contribute to additional dynamic effects, such as greater choice and additional service.

117. More liberal opening hours are thus likely to enhance structural change in the retail sector by favouring large establishments. Restrictive opening hours reduce the return on investment by larger retailers, as they tend to have higher investment in real estate and inventories than small shops (EC, 1996a). Large shops are also more dependent on hired labour. Longer opening hours thus reduce the proportion of fixed overhead costs in the total cost structure of retailers.

118. Some groups, including some consumer groups, have tended to oppose more liberal opening hours. The greatest resistance has come from owners of small shops, as these tend to have more difficulties in expanding opening hours. However, consumers with sufficient time to shop, or those not owning a car, may also oppose more liberal hours, as these could threaten neighbourhood stores and thus reduce shopping convenience for some. In general, however, and as discussed above, consumer welfare is markedly enhanced if opening hours are liberalised.

119. Trade unions and shop employees have sometimes also opposed the liberalisation of opening hours, as it might force employees to work longer hours. However, in many countries working hours are already regulated in labour legislation. Additional legislation on shop opening hours to prevent employees from working long hours may thus not be required. For instance, French shopping hours on weekdays and Saturdays are quite liberal, but are effectively restricted by labour laws (EC, 1996a). Another important concern for employees is whether or not firms are willing to pay a premium for evening and weekend hours, which likely depends primarily on the relative bargaining strength of employees and firms in the distribution sector. The low degree of organisation in this sector and the large share of part-time and informal labour in this sector suggest that the employees' bargaining strength in this sector may be relatively low.

120. A survey of about 5,000 retail workers in the United Kingdom (Freathy and Sparks, 1993) suggests that a majority of Sunday workers in the retail sector see no disadvantages to Sunday working. Most choose to work on Sunday for financial reasons and about 70 per cent receive at least one and a half the normal pay rates for working that day. This was partly the case for the food segment of the market; fewer Sunday workers in do-it-yourself (DIY) stores received premium payments -- or received lower premiums. A substantial proportion (34 per cent) of these workers were on short-term contracts, of less than 10 hours a week, suggesting that they only worked on Sundays. A follow-up study (Freathy and Sparks, 1995) showed that managers of these stores were more dissatisfied with Sunday working than most other categories of workers. For managers, Sunday 
opening often meant extra work, most working one in three Sundays. Many managers felt 'forced' to work on Sunday under contract or career pressures.

121. The recent change in opening hours in Germany may also change employment patterns in retailing (Meyer-Ohle, 1996). Employment in retailing will rise somewhat, but most of it will be part-time employment. Employees who work evenings or Saturday afternoons are likely to receive premium payments of about 20 per cent. Currently, there appears only a limited willingness of regular employees to work during the new opening hours, although studies before the regulatory change suggested that a considerable number of employees wanted to work outside the regular hours (Box 3).

122. Even when opening hours are liberalised, not all retailers are likely to expand their opening hours; for instance, if they see few opportunities for higher sales or profits in their market segment. However, where consumer demand for more flexible hours is strong, (large) retailers are likely to expand opening hours. Average opening hours are therefore likely to expand, and a greater variability in opening hours among stores may emerge.

\subsubsection{Zoning and Planning Policies}

123. Most countries regulate the siting of retail stores by local and urban planning (zoning) laws. Such regulations are closely related to land use policies and normally classify areas into certain uses. They are generally aimed at limiting the negative externalities of land use related to urban and environmental impacts.

124. Over the past years, retail planning policies have become an important policy instrument and the debate on its impacts has intensified (Davies, 1995). Underlying the debate are a number of conflicting policy interests. One is based on the benefits that a modern and efficient retail industry can deliver to consumers in terms of lower prices and a wide range (and better quality) of goods. Another suggests that consumers should have equal access to such benefits and often gives greater weight to in-town centres and environmental aspects. In the United Kingdom and some other European countries, the debate has mainly focused on whether to establish new shopping areas "intown" or "out-of-town".

125. The planning discussion -- which appears to play a more important role in Europe than elsewhere in the OECD -- has gone through a number of phases in different countries (Davies, 1995). Currently, most European countries are cautious further to enhance out-of-town developments. Legislation on large stores -- in general established out-of-town -- have become more restrictive in several countries (France, Italy, Belgium, Spain and Portugal), while the United Kingdom has also stated the need to give greater emphasis to town and city centres.

126. Retail planning policies typically try to achieve several policy goals at the same time, namely the long-term development of the retail sector, protection of social and environmental values, and the encouragement of competition. In some cases, competition appears to have suffered under planning laws. Competition authorities in several countries have investigated whether zoning laws are used to restrict competition. In Sweden, the authorities found that in certain cases only established chains and retailers were given the chance to establish in new housing areas (SCC, 1997). In Germany, shop operators that want to establish are obliged to prove that the opening of a new store will have no feasible impact on the situation of retailers in the city centre (Meyer-Ohle, 1996), which 
appears clearly aimed at protecting these retailers. In Italy, the interests of small and established retailers appear to have influenced the decisions of local authorities.

127. Planning regulations can also be rather rigid. Some countries, e.g. the United States, have therefore implemented more flexible zoning laws. For instance, incentive zoning allows for a tradeoff between the various standards set out in the original zoning law (Betancourt, 1993). The Netherlands has recently introduced -- on an experimental basis -- more flexible zoning laws in the four largest cities, with the explicit purpose to stimulate low-skilled employment. In some cases, zoning laws could also be made more transparent and might include a more thorough evaluation of costs and benefits of zoning requirements.

\subsubsection{Restrictions related to vertical relations}

128. Another important set of regulations concerns the vertical relations between wholesalers and retailers and between distributors and producers (OECD, 1992). Although these restrictions arise from competition legislation and are intended to promote competition, some of them are increasingly regarded as being anti-competitive. The most important restrictions are related to vertical restraints (both price and non-price).

129. These regulations limit the restraints which producers can impose upon distributors, both as regards price (e.g. resale price maintenance) and as regards non-price aspects (such as exclusive dealing, territorial restraints, services provided or assortment). Competition policy authorities have generally tended to ban vertical price restraints, but to tolerate some types of non-price restraints.

130. In recent years, this view has been increasingly criticised as several types of vertical restraints are being regarded as competition- and efficiency-enhancing. A number of arguments are put forward in this respect:

- A complete ban on vertical price restraints takes no account of the market power of the firms engaged. Firms with little or no market power are unlikely to distort competitive conditions when applying vertical restraints.

- Vertical restraints may provide a new retailer with secure financial resources, from which further investments can be made, potentially enhancing competition in the distribution network.

- Vertical restraints may also prevent "free-riding" behaviour by distributors on (service) costs made by other distributors. This is particular the case if the demand for a particularly product depends on the quality of services provided by its distributor.

- In practice, a proper distinction between price and non-price restraints is not easy to make. Producers can often achieve the same goals by non-price restraints as they can by price restraints.

131. Restrictions on vertical restraints appear to have effectively restricted competition. For instance, the restrictive stance of EU competition legislators against franchise agreements in the past has discouraged firms from entering in such agreements and may have contributed to the slow development of franchising practices in Europe. Some changes in EU legislation have been made on this issue in recent years, however. In principle, franchising arrangements are still forbidden under 
Article 85(1) as they are seen to reduce competition among distributors of the same goods (EC, 1996a). However, franchising is now also seen to contribute to competition, as such arrangements allow independent retailers to open a store much more easily. The European Commission has therefore granted a block exemption of Article 85(1) for distribution and service franchises, with the exception of wholesale franchises. Franchising is thus formally allowed under EC legislation, provided that franchisees are free to sell to other franchisees and are not restricted in their pricing, sales and sourcing strategies. This view is quite problematic for most franchises, as it restricts the development of a common pricing and sourcing strategy.

132. The European Commission has recently released a discussion paper on vertical integration (EC, 1997). It discusses the dilemma that improved vertical integration between producers and distributors may contribute to higher efficiency on the one hand, but be anti-competitive on the other. Some of the suggestions of the EC would go towards more extensive exemptions, or reduced scope, of Article 1985(1).

\subsubsection{Other regulations}

133. A wide range of other regulations affect behaviour in the distribution sector. For some products, such as tobacco, alcohol and pharmaceutical products, many governments strictly regulate sales, sometimes by giving a monopoly to state-owned shops. Minimum-price laws, as well as restrictions on pricing and promotion, also affect behaviour in the distribution sector, particularly as regards sales of food products. Strict permitting and licensing requirements may create an entry barrier for new stores. The evidence on the impact of these types of regulations on performance in the distribution sector is somewhat more fragmented than that on large-scale outlets and opening hours.

\section{Limitations on pricing and promotion}

134. Several countries, particularly in Europe, impose limits on the pricing and promotion policies of stores (EC, 1996a). For instance, Belgium has a detailed regulation on this issue, covering special promotions, sales, closing down sales, discounts and free gifts (EC, 1996b). Several promotional techniques are also prohibited in Denmark, Germany and the Netherlands. Italy and France take an intermediate position. Italy strictly regulates closing down sales and sales in general, whereas France obliges retailers to indicate both the original and the new price in case of price reductions, and discounting (sales below costs) is only allowed during two 6 week periods. Sales below costs has recently been regulated in a number of countries, generally with the aim to protect smaller manufacturers and retailers (Box 4).

135. These types of restrictions, such as controls over comparative advertising, may reduce incentives to compete on price (OECD, 1992). In addition, prohibitions against certain discount practices, such as special rebates, may reduce incentives to engage in price-cutting. Finally, requirements to maintain advertised prices may facilitate tacit collusion among stores by disallowing discounting practices. Many of these regulations effectively limit competition, in particular for new entrants. They also may impede economies of scale that large retailers could obtain by engaging in a nation-wide or international promotion campaign (EC, 1996a). 
136. A number of countries limit sales of certain products to a small range of (often state-owned) stores. For instance, in Japan, entry of new shops to sell liquor is restrained by a number of measures, although some easing of restrictions took place in 1995 allowing large-scale stores to sell liquor. At the same time, however, the prohibition on the resale of liquor licenses was strengthened, thus further restraining access to the sector.

137. A report in the context of the Hilmer reforms in Australia (Industry Commission, 1995) focused on the competitive situation of pharmacies. Three main barriers were noted, namely occupational regulations that limit the number of drug stores a pharmacist can own, restrictions on new stores and rules that restrict non-pharmacists from owning drug stores. The first two were considered to have substantial effects on productivity and prices. Limits on the number of pharmacies owned by one pharmacist may reduce economies of scale and could increase costs and price levels. Restrictions on new pharmacies were the result of a requirement that new pharmacists should prove to the Health Insurance Commission that there is a need for a new pharmacy in the area. The effect of this type of restriction is the creation of a local monopoly that restricts consumer choice and raises prices. The Industry Commission estimated that liberalising these two main restrictions could reduce retail margins on pharmaceutical products by some 15 per cent.

138. Similar restrictions exist in several European countries (USITC, 1995). The Scandinavian countries (Finland, Norway and Sweden) limit liquor sales to state-owned stores, and in France the opening of a pharmacy or a store selling tobacco products is tightly regulated. Tobacco sales are also tightly regulated in Italy, Portugal, Spain and Germany, while pharmaceutical stores are regulated in Austria, Finland and Sweden. In early March 1997, the European Court preliminary ruled that Sweden's public monopoly on the sale of alcoholic beverages was a disproportionate measure to safeguard public health. Other measures, such as licensing systems might be used alternatively to protect consumers from alcohol abuse.

\section{Permitting and licensing requirements}

139. In many countries, retailers that want to establish have to confirm to rather detailed requirements (EC, 1995). For instance, until recently, the Netherlands' Business Establishment Act created high barriers to entry to the sector by demanding that retailers had general business education, as well as more detailed professional skills. In 1996, an new Establishment Act was introduced that replaced these detailed requirements by more general ones. For some types of establishments, no legal entry barriers exist anymore. For others, e.g. bakers and butchers, general business skills are required. Only establishment in a third group requires specific qualifications.

140. Most countries in the European Union have similar requirements as the Netherlands on entry into retailing. Most countries require certain minimum management or professional skills. These are primarily intended as a control on the competence of new entrants. In some cases, e.g. in France, persons wanting to establish a business also need to have a clean criminal record. Other countries have fewer requirements. In Denmark, self-employed (including shopkeepers) are allowed to establish if they are Danish subjects, have their residence in Denmark and are over the minimum age. Individuals covered by EC rules are currently also allowed to establish. In most countries, new entrants also have to notify the commercial register. 
141. Empirical evidence on the effects of licensing requirements appears quite scarce. A recent study for the Netherlands found that entry rates for shop types with high requirements for professional skills, such as butchers, bakeries and pharmacies, are lower than for shops with more limited professional requirements (Carree and Thurik, 1996). The same study found that minimum requirements on floorspace limited entry.

\subsection{Evidence from cross-country studies}

\subsubsection{The impact of distribution margins on price levels}

142. Distribution margins are a frequently used measure of comparative efficiency in the distribution sector. The evidence reported in Section 2 indicated substantial differences among countries. Although high distribution margins may not always imply inefficiency (see Section 2), they may contribute to high price levels. Some evidence on this point is shown in Table 3.2, as a simple (pooled) cross-country regression of distribution margins and comparative price levels yielded a significant positive link between the two variables ${ }^{21}$. The equation suggests that a 1 percentage point increase in the distribution margin in a particular category of goods would lead to almost a 0.5 percentage point increase in the (relative) price level of that category of goods.

143. Thus, there is some evidence that distribution margins contribute to high price levels. However, what explains high distribution margins and to what extent do regulations play a role in explaining cross-country differences in margins? A particularly thorough study (Nooteboom, Thurik and Vollebregt, 1988) suggests that differences in margin are the result of differences in costs and productivity, average shop size, assortment composition and services provided, and the growth rate in consumer spending (a cyclical variable). By affecting any of these variables, regulations can influence distribution margins, although the most important effect is likely to arise from the impact of regulations on productivity and average shop size. As discussed above, restrictions on large-scale outlets can play a prominent role in reducing productivity growth and limiting shop size.

144. Some other studies have analysed distribution margins across countries (O'Riordan, 1993; Den Hertog, Potjes and Thurik, 1994; Den Hertog and Thurik, 1995; Betancourt and Gautschi, 1996; Burt and Sparks, 1997). The study by O'Riordan looks at gross retail margins in seven countries, namely Britain, France, Germany, the Netherlands, Denmark, Ireland and the United States. It found that these margins were -- on average -- the highest in the United States. Some explanations

21. The equation is based on pooled data, covering distribution margins and comparative price levels for 10 categories of goods (food and beverages, tobacco products, clothing, leather products, furniture, books and printed goods, drugs and medicines, cleaning and toilet goods, household appliances and motor vehicles) and 10 countries (United States, Japan, Germany, France, United Kingdom, Canada, Australia, Austria, the Netherlands and Sweden). The distribution margins were derived from input-output tables for the countries concerned and were calculated as the difference between (consumer) expenditure at purchaser prices and at producer prices. To the extent possible, indirect taxes and subsidies were excluded from the distribution margin.. The distribution margins are mostly for the late 1980s or early 1990s. Comparative price levels were derived for the same categories of goods from OECD's PPP database (OECD, 1990; 1993) and cover 1990. Country- and sector-specific dummies were included in the equation to represent these fixed effects. Both were significant. 
mentioned in the study for the differences in margins across countries were structural differences, differences in consumption expenditure patterns, differences in excise taxes and measurement problems. The O'Riordan study still regards retail margins a good measure of the efficiency of the distribution sector, a position which is generally not taken by later studies.

145. The second of these studies (Den Hertog, Potjes and Thurik, 1994) focused on retail margins in Japan and Germany. It found that Japanese retailers could pass on more of their operating costs to consumers than German retailers, that German retailers can achieve greater economies of scale by increasing shop size than Japanese retailers, that Japanese retailers received a higher basic income from sales than German retailers and that Japanese retailers had less need for advertising or high service to survive. All these factors helped to explain the high presence of small stores in Japan.

146. The third study (Den Hertog and Thurik, 1995) looked at price setting in Dutch and German retailing. This study found that Dutch retailers could pass on more of their costs than German retailers, which appeared related to the smaller size of Dutch retail firms. Dutch retailers received a lower basic income from their sales than German retailers, however, which is in contrast with the Japanese experience discussed above. The authors attributed some of the higher presence of small firms in the Netherlands and its effect on price setting, to restrictive government policies as regards large stores and hypermarkets.

147. A fourth study (Betancourt and Gautschi, 1996) analysed retail margins in France, Germany and the United States. This study notes that gross margins should be considered the output of retail firms. The associated distribution services should be classified into five areas, namely accessibility of location, assortment, assurance of delivery in the desired form and at the desired time, information and ambience. The study finds a wide range of retail margins in each country, with the lowest margins being observed for gasoline dealers and the highest margins for liquor stores (Germany), bookstores (France) and florists (United States). Differences in classification make detailed quite possible, however. The study uses a regression analysis to 'explain' some of the differences in margins. Margins are found to be higher if specific distribution services are provided and lower if distribution services are not easily accessible to consumers.

148. A particularly interesting study is a recent comparison of retail margins in the United Kingdom and France (Burt and Sparks, 1997). The study found that UK retail margins of major retailers -- operating margins and pre-tax margins -- were significantly higher than French margins. However, this was partly due to higher investment by UK retailers, as the return on capital between major retailers differed only little between the two countries. Looking in more detail at the differences in margins, the study notes several factors that contribute. First, accounting practices differ substantially between the two countries. Second, ownership structures and sources of finance differ between the two countries, with UK retailers having to extract much funding from the Stock Exchange. This also implies that profits are an important yardstick of performance for these companies. Third, cost structures differ. UK retailers have lower labour costs, smaller inventories, more centralised buying, higher scale economies and provide less customer credit than French retailers. Land prices may also play a role, as planning legislation and a physical shortage of land was thought to driven up land prices above levels prevailing in France. Fourthly, regulations may have had some impact. As discussed above, the Loi Royer appears not to have slowed down the development of hypermarkets in France, but may have slowed down the development of commercial centres and service-oriented retailers. These types of shops have developed further in the United Kingdom and as they provide higher service, they are also likely to have higher margins than hypermarkets. As the 
study notes, competition on price appears to be more important in France than in the United Kingdom.

149. A recent evaluation of distribution margins is provided by a study by the European Commission (EC, 1996a). This study looked at the development of consumer and producer prices over time for a number of EU countries and found a diverse picture. In Germany and the Netherlands, the distribution margin appears to have narrowed over time, as producer prices increased substantially relative to consumer prices. The opposite appears to be the case for Spain, the United Kingdom and, to a lesser extent, France. In principle, this implies that manufacturers have mainly gained from price developments in Germany and the Netherlands, whereas retailers (or wholesalers) have gained from price movements in Spain and the United Kingdom. Qualitative evidence by the same study points to a reduction in distribution prices (margins) in the wake of European integration, possibly resulting from increased vertical integration in the distribution chain and increased competition.

\subsubsection{The effect of regulations on the size and density of retail outlets}

150. As discussed above, restrictions on large-scale stores may slow down the growth in the average size of outlets and the reduction in the density of outlets. Regulations are only one factor, however, as the density of retail outlets depends on a range of demand-related phenomena, such as population density, urban concentration and personal consumption. To analyse the role of these factors in more detail, time series for outlet density and a number of important explanatory variables were obtained for 8 OECD countries, namely the United States, Japan, Germany, France, Italy, the United Kingdom, the Netherlands and Sweden. A regression equation was estimated for outlet density, including five demand-related variables, namely:

- population density (number of inhabitants per square kilometre);

- urban concentration (measured as the sum of the squared shares of the ten largest urban areas in total population), intended to capture agglomeration economies;

- per capita consumption;

- the number of cars per capita, proxying consumer mobility;

- female labour force participation, proxying the opportunity cost of time spent shopping.

151. The first two variables are expected to have positive signs. The effect of the third variable is less obvious. It captures a number of effects. First, if consumption rises the demand for wider consumer choice and for higher service is likely to increase. This may result in a demand for larger outlets, which generally offer a wider variety of goods and services, although some compensation may emerge from an increase in smaller speciality stores. However, on the whole a decline in small outlets should be expected. The sign of this variable is thus expected to be negative.

152. The fourth variable, the number of cars per capita, is also a somewhat complex variable. A high value of this variable should expand the size of the market for all outlets, should expand the market related to the sale of cars and petrol and should enhance the competitiveness of large outlets, notably those involved in the distribution of convenience goods. This variable is therefore expected to have a slight positive impact on the density of non-food retail outlets, but a negative impact on that of food retail outlets. The final demand side variable, the female labour force participation rate, is 
generally expected to have a negative impact on outlet density. A higher participation rate should probably increase the size of the average purchase, reflecting a higher overall opportunity cost of shopping, and thus favour larger stores.

153. On the supply side, only one variable is included in the basic estimation, namely the relative price of land -- proxied by the price index of rents relative to the CPI. Larger outlets should in principle make greater use of land and this variable might therefore be expected to have a positive sign. However, on the other hand, the price of land may also provide an incentive for outlets to expand outside areas with high land costs, thus leading to an increase in large outlets and a subsequent fall in the density of retail outlets. The sign of this variable may thus ultimately prove to be negative.

154. To represent regulatory restrictions on large-scale outlets, three dummy variables were included in the regression equation. Among the eight countries covered (France, Germany, Italy, Japan, the Netherlands, Sweden, the United Kingdom and the United States), only France (Loi Royer 1974), Italy (Commercial Law - 1971) and Japan (Large Scale Store Law - 1973) have specific legislation covering large-scale outlets (OECD, 1992; McKinsey, 1994), even though these restrictions have been eased somewhat over the past decade. The dummies are therefore expected to have a positive impact on the average density of outlets.

155. The regression results are in general quite good. They are best for food retail outlets (Table 3.3), where the influence of the various demand- and supply-side variables is more straightforward than in non-food retailing. Here, the variables all have their expected signs -including a negative sign for land prices -- and are highly significant. Nevertheless, even for total retailing the basic thrust of the results holds up, although some of the variables lose in explanatory power, and for a few variables the signs are not as clear.

156. The dummy variables for Japan, Italy and France are highly significant and would, if rendered inoperative, lead to a substantial fall in the predicted number of food retail outlets in these countries, but particularly in Japan and Italy. The significance of the dummies implies that there are country-specific factors for these three countries that have slowed down the reduction in outlet density and consequently the growth of average store size. Restrictions on large-scale stores are a probable factor, although other variables can not be excluded. For instance, for Japan, the lack of storage space at home may also have contributed to the need for frequent and close-by shopping (Flath, 1990). The dummies for Japan, Italy and France remain significant in the equation for total retailing, although the coefficients for Japan and France are much lower than they were for food retailing.

\subsubsection{Productivity differences and regulations}

157. Inappropriate regulation could reduce the efficiency of the distribution system and thus lead to lower productivity growth. In practice, there are two ways to analyse whether regulations have had an impact on productivity performance. A first method would analyse whether productivity growth has fallen following the introduction of restrictive regulation (or increased after the liberalisation of such legislation). A second method would analyse whether countries with less restrictive rules have had better productivity performance than countries with strict legislation. Both methods are briefly discussed in this section.

158. Another look at productivity growth in the distribution sector across the OECD area suggests that regulations may have had some impact (Figure 2.1). The graph shows four panels of countries, with the bottom-left hand corner covering countries that introduced legislation on large 
stores during this period (Japan, France, Italy and Belgium). In most of these countries, productivity growth appears to have slowed down following the introduction of such legislation or its strengthening (1974 and 1979 in Japan, 1973 in France, 1971 in Italy, and 1975 in Belgium). However, it is unclear to what extent other factors have played a role in slowing down productivity growth during this period. For instance, in a number of countries the introduction of legislation coincides with the 1973 oil crises and the resulting depression (Burt, 1984). The link suggested by Figure 2.1 is therefore insufficient to make a convincing case for a link between regulation and productivity performance.

159. Cross-country productivity comparisons suggest a stronger impact of regulations on performance (Baily, 1993; McKinsey, 1994, 1995, 1996). These studies focused on productivity in general merchandise retailing and covered productivity in the United States, Japan, Germany, France, Spain and Sweden ${ }^{22}$. Estimates of comparative productivity reported in these studies suggest considerable cross-country differences (Table 3.4).

160. The McKinsey work, primarily based on industry expertise, suggested a strong relation between product market factors, including regulatory structures, and the resulting productivity performance, although other factors, such as land constraints were also acknowledged. For the countries studied, the following policies were suggested to have an impact on productivity performance:

- In Japan, both labour and capital productivity were estimated to be substantially below US levels. High land prices and restrictions on land use appeared to create strong entry barriers, reducing competition (McKinsey, 1996). In addition, the LSRS law and other zoning regulations limited entry and slowed down the introduction of new, and more productive, retail formats. The difference in retailing formats (see Section 2), was estimated to explain almost half of the US-Japan productivity gap in the retailing sector.

- In Germany, labour and capital productivity are quite close to that in the United States (McKinsey, 1996). However, high land prices (partly resulting from regulatory impediments) restricted entry, whereas restrictions on shop opening hours slowed down the evolution of retailing formats and reduced the performance of the shops. On the other hand, short opening hours also appear to have increased throughput to the sector (sales have to be made in a shorter period, increasing labour utilisation), therefore raising measured productivity to US levels.

- In France, productivity was slightly below that in Germany (Baily, 1993; McKinsey, 1995). The gap with the United States and Germany was partly attributed to the impact of restrictions on large stores (McKinsey, 1994). The slow development of such large stores was also seen as contributing to the slow development of small specialised stores, that often rely on large stores (and each other) as an "anchor" (McKinsey, 1994).

- In Sweden, productivity was somewhat below the levels in France and Germany. The productivity gap was partly attributed to competition conditions (Swedish retailing is

22. General merchandise retailing excludes eating and drinking establishments, food and liquor stores, convenience stores, pharmacies, car dealers and oil and gas retailers (McKinsey, 1995). 
among the most concentrated in Europe) and protection by local governments of existing retailers (McKinsey, 1995; OECD, 1997c).

- In Spain, productivity is substantially below that of the other countries. To a large extent, this is the result of the less developed state of the Spanish retailing sector. No national restrictions on large stores existed at the time of the McKinsey analysis. However, local and regional planning laws were also considered to considerably deter entrants, as the approval process is considered to be quite lengthy and costly (McKinsey, 1994).

\subsubsection{Price Comparisons}

161. Comparisons of retail prices are a traditional tool to study cross-country differences in performance. Cross-country price differences receive considerable attention in the press and may sometimes provide helpful insights. However, price comparisons face several methodological difficulties (McGoldrick, et al., 1995; Burt and Sparks, 1997) and it is unclear how far they contribute to the understanding of performance in the distribution sector.

162. An overview of price comparisons and its uses is provided by a report for the Office of Fair Trading (McGoldrick, et al., 1995). Price comparisons are undertaken by international organisations, such as OECD (OECD, 1996c) and the United Nations (United Nations, 1992), by commercial organisations and by national governments. The purposes of these studies differ considerably, as do the methodologies used. In general, the price comparisons are made on the basis of a basket of goods, that are priced in as many countries as possible. Among the main problems are the definition of the products and the choice of products (Burt and Sparks, 1997). In addition, the choice of retail outlet where a product is being priced and the distribution services provided with the product can greatly affect the measured price. Other sources of mismeasurement are excise taxes, brand images and regional differences. Price comparisons across countries are also always relative to a common yardstick, namely the exchange rate.

163. These issues, and others, imply that retail price differences across countries are difficult to interpret and are possible influenced by considerable measurement error. More importantly, price differences may arise from a wide variety of sources, the distribution sector being only one. The distribution sector forms the end of a chain from producer to consumer, but the retail price is determined not only by the costs and margins of the distributor, but also by the producer and other firms in the distribution chain. For these reasons, price comparisons are given little weight in the current overview of cross-country studies on the distribution sector.

\subsection{The impact of European integration}

164. The 1992 integration of the European market presents a case study of a significant change in regulatory structures affecting the distribution sector. It has been studied by both the European Commission (EC, 1993, 1993a, 1994, 1996) and by EFTA (EFTA, 1994). The main effects of European integration of interest here are the increase in international competition, following the reduction in trade barriers, and the enhanced possibilities to exploit economies of scale. Other elements of European integration (EC, 1993a), such as the harmonisation of standards, protection of 
consumers and removal of tax barriers, are also important for the performance of the distribution sector.

165. There are a number of effects one would expect to arise from EU integration. First, an integrated market should strengthen the position of large firms and further enhance the market power of distributors relative to manufacturers. Larger retailers will be able to use even greater buying power with producers, particularly if they work together in buying groups. The process of scale enlargement will imply greater pressure on traditional retailers, particularly in those countries where the retail sector is not yet very advanced. The process of scale enlargement may lead to higher concentration in some domestic markets, but the increase in internationalisation is likely to undercut the increase in market power of domestic retailers. These developments indeed appear to have occurred. Large retailers have benefited particularly from European integration and have expanded their operations in foreign markets. Small shops have come under greater pressure (EC, 1996a).

166. Second, the larger market size would enable distributors to rationalise their operations and benefit from economies of scale. It would particularly allow distributors to reduce procurement costs, as they can more easily look for cheaper sources of supply abroad. Lower transport costs, easier border crossings and harmonised standards have all simplified access to foreign sources of supply, allowing distributors to reduce procurement costs substantially. This development also appears to have occurred (EC, 1996a). Procurement) patterns appear to have changed and many retailers have moved from domestic to EU procurement.

167. European integration has also re-inforced a number of developments in the distribution sector. Foremost among these is the increasing degree of vertical integration in the distribution chain from producer to consumer. Theoretically, the efficiency of the distribution chain can be optimised when the chain is fully vertically integrated (EU, 1996c), either by one firm controlling the whole chain or by perfect co-ordination between the different functions. In practice, this has led to increased distribution activities of manufacturers and major retailers, with a much smaller role for wholesalers. While the position of wholesale companies has declined substantially, specialised logistics companies have filled some of the void as retailers and manufacturers contracted out much of their distribution activities to such companies.

168. The integrated market has also led to more centralised production by manufacturing firms. This has had a substantial impact on distribution, as manufacturing firms could centralise their distribution in regional or European-wide distribution centres. Technological changes have facilitated such changes.

169. Recent evaluation studies of the European Commission (EC, 1996c) suggest that the Single Market has already led to considerable efficiency gains and contributed to lower costs of distribution services. These gains appear to have been passed on to consumers and producers, both in terms of greater choice in distributors and in lower prices. Improved performance in the distribution sector is estimated to have reduced transport and warehousing costs between 1987 and 1993 by some 30 per cent (EC, 1996a). In addition, the average number of days from order placement to delivery dropped from 21 days in 1987 to 15 days in 1992 . Quality also appears to have improved, as service failures are estimated to have declined by 31 per cent over this period. 


\subsection{Concluding remarks}

170. Although the evidence is scattered and further research on the link between regulation and performance in the distribution sector appears required in several areas, much of the evidence appears to point in the same direction. A wide range of regulations, including restrictions on large stores, opening hours and zoning, appear to have slowed down structural change in the distribution sector. These regulations has sometimes affected the efficiency of the distribution system, but mostly they appear to have influenced the range of services provided to consumers.

\section{Box 2: The deregulation of shop opening hours in Sweden}

Regulations on the opening hours of stores were abolished in 1972. However, the Working Hours Act imposes restrictions on actual working hours. The effects of the deregulation have been evaluated on a number of occasions, most recently in 1991. A study by the Civildepartement (Civildepartement, 1991) found the following effects of the reform:

- Average opening hours of stores providing daily consumer goods rose from about 53 hours in the early 70s to about 63 in 1989. Hypermarkets and department stores expanded their hours by 6 hours on average, while the opening hours of clothing and furniture stores changed only little.

- Most (80 per cent) of department stores and hypermarkets are now open on Sundays. About 48 per cent of furniture stores are now opened on Sundays and about half of all convenience stores are open on Sunday.

- Turnover rose by 5 per cent as a result of the liberalisation.

- Prices fell by 0.6 per cent.

- Profits rose by 3.6 per cent.

- Employment rose by 1.5 per cent. Consequently, productivity -- if measured by turnover per employee -- rose substantially.

Several of these effects are based on a comparison of the initial situation (in 1974) and the situation in 1989. For others (sales, prices, profits and employment), the effects of deregulation had to be distinguished from other trends in the sector.

Another important effect of the deregulation was the structural transformation of the sector (Kremers, et al., 1994; Nooteboom, 1994; SCC, 1997). The market share of hypermarkets and large supermarkets (over 400 square metres) rose from 30 per cent in 1970 to 70 per cent in 1993 . Small and medium-sized supermarkets were the main losers from the deregulation, as their market share fell from 70 per cent in 1970 to only 19 per cent in 1993. Convenience stores and traffic-related stores were the main new entrants to the sector, as these stores were able to benefit from the longer hours. Their market share had risen to 11 per cent by 1993 . 


\section{Box 3: The liberalisation of shop opening hours in Germany and the Netherlands}

\section{Germany}

A major liberalisation of shop opening hours took effect in November 1996. Closing time on weekdays was changed from 18.30 p.m. to 20.00 p.m., and on Saturdays from 14.00 p.m. to 16.00 p.m. The implications of deregulating shop opening hours were studied in detail by the IFO institute in 1995 at the request of the German government (Ifo Institute, 1995). The study comprised detail surveys among retailers, employees and consumers as to how current legislation affects their behaviour and how they might respond to relaxation or abolition of the regulations. The results of these surveys were then used to assess the implication for turnover, structural change, productivity and employment in the retail sector. The results of the surveys were as follows:

- Forty per cent of all retailers would increase their opening hours if restrictions were to be abolished, and 26 per cent per cent were in favour of complete liberalisation of shop opening hours. Large-scale retailers were strongly in favour of liberalisation, and would take advantage of the freedom to set opening hours.

- Only a minority of consumers (20 per cent) reported having difficulties with their shopping because of restrictions on shop opening hours, and only a fifth expected to increase their spending as a result of longer hours.

- A large number of employees claimed to be prepared to work outside current shop opening hours, suggesting that current legislation may be protecting employees against their will.

On the basis of these results, the IFO institute estimated that turnover in retailing could increase by $2-3$ per cent over a three year period as a result of complete liberalisation of shop opening hours. The gains would be concentrated on large-scale outlets, which could see their turnover increase by 5-7 per cent, while smaller stores could expect to see a decline in their sales of 1-2 per cent. Given the higher productivity levels in large stores, full-time employment would increase by only 1.3 per cent ( 31 to 32 thousand). However, since the employment gains would be concentrated on part-time employment, there would be a much sharper increase in the number of persons employed, and total employment in retailing could increase by 2 per cent. There is little evidence if the introduction of the new legislation is changing performance and shopping behaviour, although the first evaluations suggest that sales and employment have not increased much yet.

\section{Netherlands}

A major liberalisation of shop opening hours was introduced in 1996. Shops now have the possibility to open from 6.00 am to 10 p.m. from Monday to Saturday with Sunday trading allowed 12 times a year. The liberalisation was analysed by several institutes and was extensively discussed by the parties involved. The most elaborate study was by CPB (CPB, 1995). They estimated that the liberalisation of opening hours could increase the number of jobs in the retail sector by about 15000 , or by about 11000 in full-time equivalents. This would represent an almost 2.5 per cent increase in retailing employment. The effects on turn-over would be quite moderate, as both prices and the volume of sales would expand by only 0.2 per cent. The liberalisation of opening hours would mainly favour large stores and thus contribute to the process of scale enlargement in the Dutch retailing sector. Profits would hardly be affected.

The first effects of the extension of opening hours are slowly emerging (CBL, 1996). About 60 per cent of all supermarkets in the food sector are now open from 8.00 to 20.00 on weekdays and until 18.00 on Saturdays. More and more consumers shop in the evening, and 34 per cent of all consumers have shifted shopping to the new hours. Spending per customer in the evening is 28 per cent higher than during the day. The employment and output effects are not clear yet, however. 


\section{Box 4: Regulating Below-Cost Selling by Food Retailers}

The practice of below-cost selling or loss-leading has been a common promotional tool in the retail food industry for many years. In an attempt to attract customers, many food retailers sell a limited range of known-value products, usually staples such as milk and bread, below cost. This practice is especially attractive to larger operations that can purchase these items at heavily discounted prices through volume buying. A number of OECD governments have expressed concerns about the impact of these practices on smaller food manufacturers and retailers, particularly where retail market power has risen through increased concentration and the growth of generic and private-label products.

Smaller, independent retailers are seen to be at competitive disadvantage. Without access to similar volume discounts, they may not be able to compete on prices and, with a smaller range of products, less able to recoup losses on below-cost items through other consumer purchases. Lossleading at the retail level may also increase price pressure on food manufacturers (and primary producers) as large retailers use their buying power to obtain further discounts and other retailers demand similar price reductions in order to compete. Smaller food manufactures/suppliers may not be in a position to offer similar discounts to retailers and hence their products may not receive equal promotion.

Consumers would appear to benefit from the lower prices on selected goods. However, there are concerns that below-cost selling on a small range of products actually restricts the number of products subject to discounts and creates a misleading impression of large retailers' overall price levels (in some cases restrictions have been placed on the advertising of below-cost prices rather than on the practice itself). Some regulators have argued consumers would benefit from the prevention of such pricing tactics because it would result in more broadly based competitive pricing. A number of OECD countries, most recently Ireland (1987), Spain (1996) and France (1997), have regulated below-cost selling to protect smaller retailers and manufacturers. The regulations have often proven difficult to enforce and appear to be of limited effectiveness.

Collins and Oustapassidis (1997) suggest that the Groceries Order 1987 banning below-cost selling in the Irish grocery market led to increased retail margins in the affected product categories. The authors point out that since the affected products tended to be staple products, a disproportionate share of the welfare loss was likely to be incurred by less affluent consumers. Moreover, there was no evidence that consumers benefited from a move to broader based price competition after the ban was in place. The regulation was justified on the basis of increasing retailer concentration and buying power, the decline of the independent sector and the pressures on food manufacturers. While these developments appear to have slowed, there was no evidence to suggest a reduction in the subsequent pressures on manufacturer margins.

The French loi Galland was introduced in January 1997 to protect smaller manufacturers by preventing the selling of products "at a price which is excessively low in relation to production and selling costs". While it is still too early to assess the full impact of the regulation, initial figures from a number of sources report an increase in prices to consumers (Eurofood, 1997). One large retailer claimed that small and medium-sized firms would not benefit from reduced price competition or higher prices as a result of the regulation. 


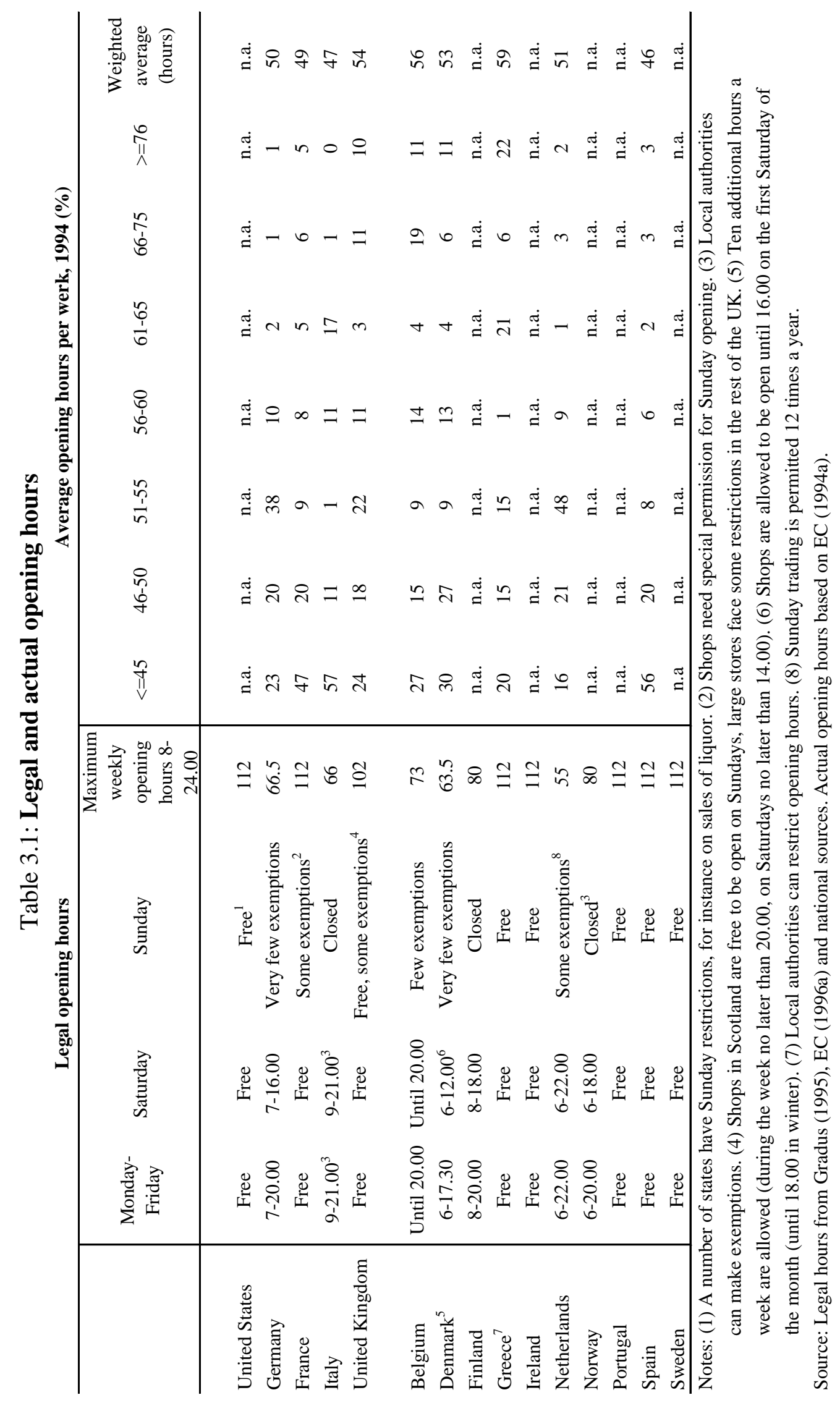


Table 3.2: Regression explaining comparative price levels (dependent variable is 1990 comparative price level) ${ }^{1}$

\begin{tabular}{lcc}
\multicolumn{1}{c}{ Variable } & Coefficient & T-statistic \\
\hline Constant & 82.15 & 6.46 \\
1985 comparative price level & 0.78 & 8.81 \\
Distribution margin & 0.46 & 2.14 \\
R2 (adjusted) & 0.685 & \\
Number of obs. & 94 &
\end{tabular}

S.E. of regression 19.46

Note: (1) Equation includes fixed country and sectoral effects.

Source: Comparative price levels from OECD (1987; 1993); distribution margins from country-specific input-output tables, see Pilat (1996) for precise references. 
Table 3.3: Equations modelling the density of retail outlets (absolute levels of T-statistics are in parenthesis)

\begin{tabular}{|c|c|c|c|c|}
\hline \multirow[t]{2}{*}{ Independent variable } & \multicolumn{2}{|c|}{ Food retail outlets } & \multicolumn{2}{|c|}{ All retail outlets } \\
\hline & 1 & 2 & 1 & 2 \\
\hline Constant & $\begin{array}{l}3.60^{* *} \\
(4.75)\end{array}$ & $\begin{array}{l}4.63^{* *} \\
(9.22)\end{array}$ & $\begin{array}{c}2.80^{* * *} \\
(10.40)\end{array}$ & $\begin{array}{c}2.60^{* * *} \\
(15.02)\end{array}$ \\
\hline Urban concentration & $\begin{array}{l}0.82^{* *} \\
(5.18)\end{array}$ & $\begin{array}{l}0.93^{* *} \\
(8.26)\end{array}$ & $\begin{array}{c}0.79 \\
(1.61)\end{array}$ & $\begin{array}{l}0.13^{* *} \\
(3.45)\end{array}$ \\
\hline Car density & $\begin{array}{c}-1.88^{* *} \\
(3.18)\end{array}$ & $\begin{array}{c}-1.27^{* *} \\
(3.52)\end{array}$ & $\begin{array}{c}-1.41^{* *} \\
(6.28)\end{array}$ & $\begin{array}{c}-1.28^{* *} \\
(8.77)\end{array}$ \\
\hline Relative price of land & $\begin{array}{c}-0.027^{* *} \\
(2.67)\end{array}$ & $\begin{array}{c}-0.017^{* *} \\
(2.75)\end{array}$ & $\begin{array}{l}-.081^{* *} \\
(2.64)\end{array}$ & $\begin{array}{c}-.065^{* *} \\
(3.23)\end{array}$ \\
\hline Female labour force participation rate & $\begin{array}{c}-2.76^{* *} \\
(4.02)\end{array}$ & $\begin{array}{c}-1.55^{* *} \\
(3.63)\end{array}$ & $\begin{array}{c}-1.46^{* *} \\
(6.82)\end{array}$ & $\begin{array}{c}-1.07^{* *} \\
(7.75)\end{array}$ \\
\hline Population density & $\begin{array}{l}1.67^{* *} \\
(8.40)\end{array}$ & $\begin{array}{c}1.34^{* * *} \\
(10.80)\end{array}$ & $\begin{array}{c}0.10 \\
(1.60)\end{array}$ & $\begin{array}{c}0.02 \\
(0.45)\end{array}$ \\
\hline Personal consumption & $\begin{array}{l}-0.42 \\
(0.28)\end{array}$ & $\begin{array}{c}-3.26^{* *} \\
(3.57)\end{array}$ & $\begin{array}{l}0.91^{* *} \\
(3.82)\end{array}$ & $\begin{array}{l}0.57^{* * *} \\
(6.95)\end{array}$ \\
\hline \multicolumn{5}{|l|}{ Country dummies for: } \\
\hline Japan & & $\begin{array}{l}0.69^{* *} \\
(9.29)\end{array}$ & & $\begin{array}{l}0.17^{* *} \\
(6.95)\end{array}$ \\
\hline Italy & & $\begin{array}{c}1.05^{* *} \\
(16.05)\end{array}$ & & $\begin{array}{c}0.33^{* * *} \\
(15.57)\end{array}$ \\
\hline France & & $\begin{array}{l}0.44^{* *} \\
(5.77)\end{array}$ & & $\begin{array}{l}0.11^{\text {*** }} \\
(4.40)\end{array}$ \\
\hline \multicolumn{5}{|l|}{ Summary statistics: } \\
\hline $\mathrm{R}^{2}$ & 0.720 & 0.901 & 0.559 & 0.828 \\
\hline Standard error of the regression & 0.419 & 0.251 & 0.128 & 0.080 \\
\hline F-statistic & 80.44 & 187.49 & 39.43 & 98.31 \\
\hline Number of observations & 195 & 195 & 195 & 195 \\
\hline
\end{tabular}

** Indicates significance at the 1 per cent level.

Source: Høj, Kato and Pilat (1996). See also OECD (1992). 
Table 3.4: Comparative productivity in retailing, 1992

(productivity in general merchandise retailing, USA $=100$ )

\begin{tabular}{lccc} 
& $\begin{array}{c}\text { Labour } \\
\text { productivity }\end{array}$ & $\begin{array}{c}\text { Capital } \\
\text { productivity }\end{array}$ & $\begin{array}{c}\text { Total factor } \\
\text { productivity }\end{array}$ \\
\hline United States & 100 & 100 & 100 \\
Japan & 50 & 65 & 55 \\
Germany & 90 & 110 & 95 \\
France $^{1}$ & 87 & n.a. & n.a. \\
United Kingdom $^{2}$ & 82 & 91 & 86 \\
Spain $^{1}$ & 73 & n.a. & n.a. \\
Sweden $^{1}$ & 84 & n.a. & n.a. \\
\hline
\end{tabular}

Notes: (1) Data are relative to the United States $=100$ for 1990.

(2) Data are relative to the United States $=100$ for 1988.

Source: McKinsey (1992; 1995; 1996). 


\section{BIBLIOGRAPHY}

Akehurst (1995), "Concentration in Retail Distribution: Measurement and Significance", in: G. Akehurst and N. Alexander (eds.), Retail Structure, Frank Cass, London, pp. 27-45.

Akehurst, G. and N. Alexander (1995), "The Internationalisation Process in Retailing”, The Service Industries Journal, Vol. 15, No. 4, October, pp. 1-15.

Australian Bureau of Statistics (1990), Australian National Accounts - Input-Output Tables 1986-87, Canberra.

Baily, M.N. (1993), "Competition, Regulation and Efficiency in Service Industries", Brookings Papers on Economic Activity, Microeconomics, No. 2, pp. 71-159.

Betancourt, R.R. (1993), "An Analysis of the U.S. Distribution System", OECD Economics Department Working Papers, No. 135, OECD, Paris.

Betancourt, R.R. and D.A. Gautschi (1996), "An International Comparison of the Determinants of Retail Gross Margins”, Empirica, Vol. 23, pp. 173-189.

Bureau of Economic Analysis (1994), "Benchmark Input-Output Accounts for the U.S. Economy, 1987”, Survey of Current Business, Vol. 74, No. 4, pp. 73-115.

Burt, S. (1984), "Hypermarkets in France - Has the Loi Royer had any effect?", Retail and Distribution Management, January/February, pp. 16-19.

Burt, S.L. and J.A. Dawson (1990), "From Small Shop to Hypermarket: The Dynamics of Retailing", in: D. Pinder (ed), Challenge and Change in Western Europe, pp. 142-161.

Burt, S. and L. Sparks (1997), "Performance in Food Retailing: A Cross-national Consideration and Comparison of Retail Margins", British Journal of Management, Vol. 8, Special Issue, pp. S119-S136.

Cabrera, C. (1995), "Retail Planning Policies in Spain", in: Davies, R.L. (ed.) (1995), Retail Planning Policies in Western Europe, Routledge, London, pp. 200-216.

Carree, M. and R. Thurik (1996), "Entry and Exit in Retailing: Incentives, Barriers, Displacement and Replacement", Review of Industrial Organization, Vol. 11, pp. 155-172.

Centraal Bureau Levensmiddelen (CBL) (1996), Dienstverlening in de avonduren (in Dutch). 
Centraal Planbureau (CPB) (1995), "Economische effecten van liberalisering van winkeltijden in Nederland" (The Economic Effects of Liberalised Shop Opening Hours in the Netherlands), Working Paper, No. 74, The Hague.

Central Bureau of Statistics (CBS) (1992), "Input-outputtabellen en input-outputcoëfficienten 1987", De produktie-structuur van de nederlandse volkshuishouding, Voorburg.

Cette, G., P. Cunéo, J.P. Herbay and B. Préel (1992), "L’impact de l'ouverture des commerces le dimanche", Travail et Emploi, No. 51, 1992-1.

Civildepartement (1991), "Betänkande av 1989 ärs äffarstidsutredning" (1989 Report of the Committee on Opening Hours), Stockholm.

Collins, A. and K. Oustapassidis, Below Cost Legislation and Retail Performance, Agribusiness Discussion Paper No. 15, Department of College Cork, 1997.

Czinkota, M.R. and M. Kotabe (ed.) (1993), The Japanese Distribution System, Probus Publishing Company.

Davies, R.L. (1995), "Preface", in: Davies, R.L. (ed.) (1995), Retail Planning Policies in Western Europe, Routledge, London.

Dawson, J.A. (1995), "Retail Change in the European Community", in: R.L. Davies (ed.) (1995), Retail Planning Policies in Western Europe, Routledge, London, Chapter 1.

Dawson, J.A. and T. Sato (1995), "Controls over the Development of Large Stores in Japan", in: G. Akehurst and N. Alexander (eds.), Retail Structure, Frank Cass, London, pp. 87-96.

Economic Planning Agency (EPA) (1996), "Provisional Estimates of the Economic Effects of Recent Deregulations", Tokyo, September.

Economisch Instituut voor het Midden- en Kleinbedrijf (EIM) (1995), "Verruiming Winkelsluitingswet - plussen en minnen, zakelijk bekeken", Zoetermeer.

Eurofood, March 13, 1997 (p.3), and April 10,1997 (p.5), Agra Europe (London) Ltd.

European Commission (EC) (1993), Retailing in the European Single Market 1993, Brussels.

EC (1993a), "Distribution", in: Market Services and European Integration, European Economy: Social Europe, Reports and Studies, No. 3, Brussels.

EC (1994), Retailing in the European Economic Area, Brussels.

EC (1994a), "Main Results of the Labour Market Survey in Retail Trade", European Economy, Supplement B, Business and Consumer Survey Results, No. 12, December.

EC (1995), Measures in the Field of Commerce in the European Union, Vol. 3: Commerce and Freedom of Establishment, Commerce and Distribution Series, No. 26, Brussels.

EC (1996), Green Paper on Commerce, Brussels, November. 
EC (1996a), Effectiveness and Impact of Internal Market Integration on the Organisation and Performance of Distribution, Final report, July.

EC (1996b), Panorama of EC Industry, 1995/96, Brussels.

EC (1996c), The Impact and Effectiveness of the Single Market, Communication from the Commission to the European Parliament and the Council, COM(96)520 final, Brussels.

EC (1997), Green Paper on Vertical Restraints in EC Competition Policy, Brussels.

European Free Trade Association (EFTA) (1994), "Distribution", in: European Economic Integration: Effects of "1992" on the Services Sectors of the EFTA Countries, Geneva.

Flath, D. (1990), "Why are there so many retail stores in Japan", Japan and the World Economy, Vol. 2, pp. 365-386.

Flath, D., and T. Nariu (1996), “Is Japan's Retail Sector Truly Distinctive?", Journal of Comparative Economics, Vol. 23, No. 2, October, pp. 181-191.

François, P. and J. Leunis (1991), "Public Policy and the Establishment of Large Stores in Belgium", International Review of Retail, Distribution and Consumer Research, Vol. 1, No. 4, pp. 469-486.

Freathy, P. and L. Sparks (1993), "Sunday Working in the Retail Trade", International Journal of Retail and Distribution Management, Vol. 21, No. 7, pp. 3-9.

Freathy, P. and L. Sparks (1995), "Flexibility, Labour Segmentation and Retail Superstore Managers: The Effects of Sunday Trading", International Review of Retail, Distribution and Consumer Research, Vol. 5, No. 3, July, pp. 361-385.

Gable, M., M.T. Topol, S. Mathis and M.E. Fisher (1995), "Entry Barriers in Retailing”, Journal of Retailing and Consumer Services, Vol. 2, No. 4, pp. 211-221.

Gadrey, J., T. Noyelle and T.M. Stanback, Jr. (1990), "Productivity in Retailing: A Comparison of France and the United States with a Focus on Supermarkets", Working Paper 90-05, Université de Lille.

Goldman, A. (1992), "Evaluating the Performance of the Japanese Distribution System", Journal of Retailing, Vol. 68, Number 1, Spring.

Good, W.S. (1984), "Productivity in the Retail Grocery Trade", Journal of Retailing, Vol. 60, Number 3, Fall, pp. 81-97.

Gradus, R.H.J.M. (1996), “The Economic Effects of Extending Opening Hours”, Journal of Economics, Vol. 64.

Hertog, R.G.J. den, J.C.A. Potjes and A.R. Thurik (1994), "Retail Profit Margins in Japan and Germany", Weltwirtschaftliches Archiv, Vol. 130, pp. 375-90. 
Hertog, R.G.J. den, and A.R. Thurik (1995), "A Comparison between Dutch and German Retail Price Setting”, The Service Industries Journal, Vol. 15, No. 1, January, pp. 66-73.

Høj, J., T. Kato and D. Pilat (1996), "Deregulation and Privatisation in the Service Sector", OECD Economic Studies, No. 25, 1995/II, pp. 37-73.

Ifo Institute, "Uberprufung des Ladenschlußgesetzes vor dem Hintergrund der Erfahrungen im In- und Ausland - Zusammenfassung der Untersuchungsergebnisse des Ifo Institute", Ifo Schnelldienst, Vol. 48, 24/1995, pp. 11-25.

Industry Commission (1995), The Growth and Revenue Implications of Hilmer and Related Reforms, Final Report, AGPS, Canberra.

Institut National de la Statistique et des Études Économiques (1996), "Tableaus Entrées Sorties 1995", Paris.

Kacker, M. (1988), "International Flow of Retailing Know-How: Bridging the Technology Gap in Distribution", Journal of Retailing, Vol. 61, No. 1, Spring, pp. 41-67.

Kay, J.A. and C.N. Morris (1987), "The Economic Efficiency of Sunday Trading Restrictions", Journal of Industrial Economics, December, pp. 113-129.

Kremers, J.J.M., R.H.J.M. Gradus and P.J.G. Heijmans (1994), "Winkelsluiting op de Helling” (Shop Closing Reconsidered), Economisch Statistische Berichten, 13 July.

Krugman, P. (ed.) (1992), Trade with Japan: Has the Door Opened Wider?, University of Chicago Press, NBER.

Kuribayashi, S. (1991), "Present situation and future prospect of Japan's distribution system", Japan and the World Economy, Vol. 3, pp. 39-60.

Lanoie, P., G.A. Tanguay and L. Vallée (1994), "Short-term Impact of Shopping-hour Deregulation: Welfare Implications and Policy Analysis", Canadian Public Policy, Vol. 20, No. 2, pp. 177188.

Logan, S.N. (1994), "Small Store Survival", International Trends in Retailing, Andersen Consulting, December, Vol. 11, No. 2, pp. 71-85.

Management and Coordination Agency (1990), 1985 Input-Output Tables, Tokyo.

Matthews, D. and D.G. Mayes (1994), "The role of soft law in the evolution of rules for a single European market: The case of retailing", Discussion Paper, National Institute of Economic and Social Research, No. 61, February.

McGoldrick, P.J., D.L. Bosworth, E.J. Betts and M.H. Duffy (1995), "International Retail Price Differences", Report for the Office of Fair Trading, Manchester School of Management, UMIST, October.

McKinsey (1992), Service Sector Productivity, McKinsey Global Institute, Washington, DC. 
McKinsey (1994), Employment Performance, McKinsey Global Institute, Washington, DC.

McKinsey (1995), Sweden's Economic Performance, McKinsey Global Institute, Stockholm.

McKinsey (1996), Capital Productivity, McKinsey Global Instititute, Washington, DC.

McKinsey (1997), Removing Barriers to Growth and Employment in France and Germany, McKinsey Global Institute, Washington, DC.

Mérenne-Schoumaker, B. (1995), "Retail Planning Policy in Belgium”, in: Davies, R.L. (ed.) (1995), Retail Planning Policies in Western Europe, Routledge, London, pp. 31-49.

Messerlin, P.A. (1993), "The French Distribution System and the Openness of the French Economy”, OECD Economics Department Working Papers, No. 138, Paris.

Metton, A. (1995), "Retail Planning Policy in France", in: Davies, R.L. (ed.) (1995), Retail Planning Policies in Western Europe, Routledge, London, pp. 62-77.

Meyer-Ohle, H. (1996), "State Regulations, Retail Structure and Employment in Germany and Japan", Proceedings of Employment Systems and Human Resources Management in Retailing: the cases of Japan, United Kingdom, Germany and France, Tokyo, October.

Ministère des Affaires Economiques de Belgique (1988), Loi relative aux Implantations Commerciales, Bruxelles

MITI (1994), "A Survey of Japan and Foreign Countries in Terms of the Cost of Industrial Intermediate Goods and Services", Tokyo, November.

Morris, C.N., R. Laslett and S. Gaysford (1993), The Economic Impact of Alternative Sunday Trading Regulations, The Home Office Research and Planning Unit, April.

Mulder, N.M. (1994), "La productivité du travail dans les services en France et aux États-Unis", Économie Internationale, No. 60, 4e Trimestre 1994, pp. 89-118.

National Research Council (NRC) (1994), Information Technology in the Service Society, Computer Science and Telecommunications Board, National Academy Press, Washington, D.C.

Nishimura, K.G. (1993), "The distribution system of Japan and the United States: A comparative study from the viewpoint of final-goods buyers", Japan and the World Economy, Vol. 5, pp. 265-288.

Nishimura, K.G. and Tachibana, T. (1995), "Entry Regulations, Tax Distortions and the Bipolarized Market: The Japanese Retail Sector", in: R. Sato, H. Hori and R. Ramachandran, Essays in Japanese Economy, Kluwer Academic Publishers.

Nooteboom, B. (1983), “A new theory of retailing costs”, European Economic Review, Vol. 17, pp. 163-186. 
Nooteboom, B. (1985), “A Mark-up Model of Retail Margins”, Applied Economics, Vol. 17, pp. 647667.

Nooteboom, B. (1994), "Theorie en empirie van winkelsluiting" (Theory and empirics of shop closing), Economisch Statistische Berichten, 16 November.

Nooteboom, B., A.R. Thurik and J.A.C. Vollebregt (1988), "Do retail margins differ between European countries? A comparative study", in: E. Kaynak (ed.), Transnational Retailing, Walter de Gruyter, Berlin.

OECD (1987), Purchasing Power Parities and Real Expenditures, 1985, Paris.

OECD (1992), "Structure and Change in Distribution Systems: An Analysis of Seven OECD Member Countries", Working Party 1 of the Economic Policy Committee, ECO/CPE/WP1(92)7, Paris.

OECD (1993), Purchasing Power Parities and Real Expenditures, Vol. 2, GK Results 1990, Paris.

OECD (1994), The OECD Jobs Study - Evidence and Explanations, 2 Vols, Paris.

OECD (1995), OECD Economic Surveys - Japan, Paris.

OECD (1996), Employment Outlook, Paris.

OECD (1996a), Services - Statistics on Value Added and Employment, Paris.

OECD (1996b), Labour Force Statistics - 1974-1994, Paris.

OECD (1996c), International Direct Investment Statistics Yearbook 1996, Paris.

OECD (1996d), Purchasing Power Parities - Vol. 1: EKS Results, 1993, Paris.

OECD (1997), Information Technology Outlook 1997, Paris.

OECD (1997a), "Business-to-Consumer Electronic Commerce - Survey of Status and Issues", Working Party on the Information Economy, DSTI/ICCP/IE(97)1, Paris.

OECD (1997b), OECD Economic Surveys - Belgium/Luxembourg, Paris.

OECD (1997c), "The Economy-Wide Benefits of Regulatory Reform - Country Notes", ECO/GEN(96)15/ANN/REV1, Paris.

O’Riordan, D. (1993), "Retail Gross Margins - Some International Comparisons", International Journal of Retail and Distribution Management, Vol. 21, No. 4, pp. 33-39.

Pelligrini, L. (1995), "Retail Planning Policy in Italy", in: Davies, R.L. (ed.) (1995), Retail Planning Policies in Western Europe, Routledge, London, pp. 144-159.

Pellegrini, L. and A.M. Cardani (1993), "The Italian Distribution System", OECD Economics Department Working Papers, No. 139, Paris. 
Pilat, D. (1996), "Labour Productivity Levels in OECD Countries: Estimates for Manufacturing and Selected Service Sectors", OECD Economics Department Working Papers, No. 169, OECD, Paris.

Potjes, J.C.A. (1992), Empirical Studies in Japanese Retailing, Tinbergen Institute Research Series, No. 41, Rotterdam.

Reardon, J., R. Hasty and B. Coe (1996), "The Effect of Information Technology on Productivity in Retailing”, Journal of Retailing, Vol. 72, No. 4, pp. 445-461.

Riethmuller, P. (1996), "Reform of the Japanese Food Distribution System: Implications for Consumers", Journal of Consumer Policy, Vol. 19, pp. 69-82.

Shaw, S.A., D.J. Nisbet and J.A. Dawson (1989), "Economies of Scale in UK Supermarkets: Some Preliminary Findings", International Journal of Retailing, Vol. 4, No. 5, pp. 12-26.

Smith, A.D. and D.M.W.N. Hitchens (1985), Productivity in the Distributive Trades: A Comparison of Britain, America and Germany, Cambridge University Press, Cambridge.

Sparks, L. (1992), "Restructuring Retail Employment", International Journal of Retail and Distribution Management, Vol. 20, No. 3, pp. 12-19.

Statistiska Centralbyran (SCB) (1989), Input-outputtabeller för Sverige 1985, Stockholm.

Stehn, J. (1987), "Das Ladenschlussgesetz - Ladenhuter des Einzelhandels?", Kiel Discussion Papers, Institut für Weltwirtschaft Kiel, January.

Swedish Competition Authority (SCC) (1997), "Regulatory Reform in Sweden”, Stockholm, mimeo.

Tanguay, G.A., L. Vallee and P. Lanoie (1995), "Shopping Hours and Price Levels in the Retailing Industry: A Theoretical and Empirical Analysis", Economic Inquiry, Vol. 33, July, pp. 516524.

United Nations (1992), Handbook of the International Comparison Programme, Studies in Methods, Series F, No. 62, New York.

U.S. International Trade Commission (USITC) (1995), General Agreement on Trade in Services: Examination of Major Trading Partners' Schedules of Commitments, Publication No. 2940, December.

Watanabe, T. (1994), “Changes in Japan's Public Policies Toward Distribution Systems and Marketing”, in: T. Kikuchi (ed.), Japanese Distribution Channels, The Haworth Press.

Waterschoot, W, van, and T. Deleeck (1992), "De Europese Distributie Anno 1992, aan de Vooravond van een Nieuw Tijdperk?" (European Distribution Anno 1992: The Dawn of a New Era?), Economisch en Sociaal Tijdschrift, No. 4. 


\section{ECONOMICS DEPARTMENT}

\section{WORKING PAPERS}

A complete list of Working Papers is available on request.

179. Measurement of Non-tariff Barriers

(July, 1997) Alan Deardorff and Robert M. Stern

178. The NAIRU-Concept: A Few Remarks

(July, 1997) Karl Pichelmann and Andreas Ulrich Schuh

177. Structural Unemployment in Finland

(July, 1997) Pasi Holm and Elina Somervouri

176. Taxation and Economic Performance

(June, 1997) Willi Leibfritz, John Thornton and Alexandra Bibbee

175. Long-Term Interest Rates in Globalised Markets

(May, 1997) Hans Christiansen and Charles Pigott

174. International Implications of European Economic and Monetary Union

(May, 1997) Norbert Funke and Mike Kennedy

173. The NAIRU in Japan: Measurement and its Implications

(February, 1997) Fumihira Nishizaki

172. The Unemployment Problem - A Norwegian Perspective

(February, 1997) Steiner Holden

171. The Reliability of Quarterly National Accounts in Seven Major Countries: A User's Perspective

(February, 1997) Robert York and Paul Atkinson

170. Confidence Indicators and their relationship to changes $n$ Economic Activity

(October, 1996) Teresa Santero and Niels Westerlund

169. Labour Productivity Levels in OECD Countries: Estimates for Manufacturing and Selected Service Sectors

(September, 1996) Dirk Pilat

168. Ageing Populations, Pension Systems and Government Budgets: Simulations for 20 OECD Countries

(September, 1996) Deborah Roseveare, Willi Leibfritz, Douglas Fore and Eckhard Wurzel 
167. Modelling the Supply Side of the Seven Major OECD Economies

(August, 1996) Dave Turner, Pete Richardson and Sylvie Rauffet

166. Size Distribution of Output and Employment: a Data Set for Manufacturing Industries in Five OECD Countries

(August, 1996) Bart van Ark and Erik Monnikhof

165. Trade and Competition: Frictions after the Uruguay Round

(July 1996) International Trade and Investment Division

164. Corporate Governance, Competition and Performance

(June, 1996) Colin Mayer

163. Fiscal Relations within the European Union

(April 1996) Peter Hoeller, Marie-Odile Louppe and Patrice Vergriete

162. Mark-ups mark-up ratios in manufacturing industries

(April 1996) Joaquim Oliveira Martins, Stefano Scarpetta and Dirk Pilat

161. Innovation, Firm Size and Market Structure: Schumpeterian Hypotheses and some new Themes

April, 1996) George Symeonidis.

160. Valuing the Right to Tax Incomes: An Options Pricing Approach (April, 1996) Teun Draaisma and Kathryn Gordon.

159. Innovation and Competitive Advantage

(October 1995) P. A. Geroski

158. Monetary Policy at Price Stability: A Review of Some Issues

(September 1995) Malcolm Edey, Norbert Funke, Mike Kennedy and Angel Palerm

157. Technical Progress, Factor Productivity and Macroeconomic Performance in the Medium Term

(September 1995) Claude Giorno, Pete Richardson and Wim Suyker

156. Ageing Populations, Pension Systems and Government Budgets: How do they Affect Savings

(August 1995) Willi Leibfritz, Deborah Roseveare, Douglas Fore and Eckhard Wurzel

155. The Determinants of Real Long-Term Interest Rates: 17 Country Pooled Time-Series

Evidence

(June 1995) Adrian Orr, Malcolm Edey and Michael Kennedy

154. An Assessment of Financial Reform in OECD Countries

(May 1995) Malcolm Edey and Ketil Hviding 
GENERAL DISTRIBUTION

\section{ECONOMICS DEPARTMENT}

\section{WORKING PAPERS}

The series of Working Papers is designed to make available, to a wider readership, selected studies which the Department has prepared for use within OECD. Authorship is generally collective, but main individual authors are named. The Papers are generally available in their original language, English or French, with a summary in the other.

The views expressed in this paper are those of the author(s) and do not necessarily reflect those of the OECD or of the governments of its Member countries.

Comment on the Papers is invited, and may be sent to OECD, Economics Department, 2 rue André Pascal, 75775 Paris Cedex 16, France. Additional copies of the Papers, on a limited basis, can be forwarded on request.

ORGANISATION FOR ECONOMIC CO-OPERATION AND DEVELOPMENT 